\title{
Effectiveness of Teaching Mathematical Problem-Solving Strategies to Students with Mild Intellectual Disabilities *
}

\author{
Oktay Göktaş ${ }^{a}$ and Ersen Yazıcı ${ }^{b}$ \\ ${ }^{a}$ Ministry of National Education, Atatürk Special Education Vocational Training Center School, Aydın/Turkey (ORCID: \\ 0000-0002-0563-0154) \\ ${ }^{\mathbf{b}}$ Aydın Adnan Menderes University, Faculty of Education, Aydın/Turkey (ORCID: 0000-0002-1310-2247)
}

Article History: Received: 20 December 2019; Accepted: 8 May 2020; Published online: 24 August 2020

\begin{abstract}
This study aims to examine the impact of teaching problem-solving strategies conducted during math class, to students with mild intellectual disabilities on their success in problem-solving. One of the qualitative research methods, the teaching experiment, was used in this study. The participants' group of the study consists of three students from the high school group of special education who were selected by the criterion-sampling method, one of the purposeful sampling techniques. The teaching of intelligent guessing and testing, making a drawing (making a drawing shape, schema, and diagram), and working backwards strategy, all of which are from the problem-solving strategies, was performed using the direct instruction method in accordance with teaching experiment methodology. During the teaching process, eight problems were taught and solved, including 4 in each strategy course plan. In total, 24 problems relating to these three strategies were studied, and the implementation process lasted nine weeks. The research process was recorded via a video camera, and all recordings were transcribed and analyzed by thematic analysis. As a result, it has been concluded that the teaching of problem-solving strategies to students with mild intellectual disabilities improves their problem-solving skills and has an impact on the problem-solving process. In light of the findings and results, it is recommended to teach problem-solving strategies to students with mild intellectual disabilities to improve their problem-solving skills in math class.
\end{abstract}

Keywords: Problem-solving strategies, students with mild intellectual disabilities, teaching experiment model

DOI: $10.16949 /$ turkbilmat.662461

\begin{abstract}
Bu araştırmanın amacı, hafif düzeyde zihinsel engelli öğrencilere yönelik matematik dersinde yürütülen problem çözme stratejileri öğretiminin problem çözme başarılarına etkisini incelemektir. Araştırmada nitel araştırma yöntemlerinden öğretim deneyi kullanılmıştır. Araştırmanın katılımcı gurubu, amaçlı örneklem yöntemlerinden ölçüt örneklem yöntemi ile seçilmiş özel eğitimin lise grubundan 3 öğrenciden oluşmaktadır. Öğretimde, problem çözme stratejilerinden tahmin ve kontrol, şekil, şema ve diyagram çizme ve geriye doğru çalışma stratejilerinin öğretimi öğretim deneyi araştırma modeline uygun olarak doğrudan öğretim yöntemi kullanılarak yapılmıştır. Öğretim sürecinde, her bir strateji ders planında 4'er adet olmak üzere 8 problem öğretimi ve çözümü yapılmıştır. Toplamda üç stratejiye ilişkin 24 adet problem üzerinde çalışılmış, uygulama süreci 9 hafta sürmüştür. Araştırma süreci video kamera ile kayıt altına alınıp, bütün kayıtlar transkript edilerek tematik analiz yöntemi ile analiz edilmiştir. Sonuç olarak, hafif düzeyde zihinsel engelli öğrencilere yönelik yürütülen problem çözme stratejilerinin öğretiminin, öğrencilerin problem çözme becerilerini geliştirdiği ve problem çözme süreçlerinde etkili olduğu sonucuna ulaşılmıştır. Elde edilen bulgular ve sonuçlar 1şığında hafif düzeyde zihinsel engelli öğrencilerin matematik dersinde problem çözme becerilerinin gelişmesi için problem çözme stratejilerine yönelik öğretimlerin yapılması önerilmektedir.
\end{abstract}

Anahtar Kelimeler: Problem çözme stratejileri, hafif düzeyde zihinsel engelli öğrenciler, öğretim deneyi modeli

Türkçe sürüm için tıklayınız

\section{Introduction}

Humans have always been in a struggle with nature, animals, plants, and their fellow creatures to sustain their lives, from the day they existed on earth. These struggles have, of course, brought with them some problems that need to be solved. From the beginning of humankind, problems have always been everywhere people exist. In this regard, people receive formal or informal education to solve these problems. Universally, children are educated in schools in preparation for life. In our country, the right to education is guaranteed by Article 42 of the Constitution, stating, "No one shall be deprived of the right to education and learning." Also, in the world, Universal Declaration of Human Rights, Paragraph 1 of Article 26 points out, "Everyone has the right to education. Education, at least, is free of charge in the primary and basic education stage. Primary education is compulsory. Technical and vocational education is open to all people". Considering the Article, "Higher education should be equally accessible to all according to their abilities," all our children should be enabled to participate in education and training and be supported in this regard. In order for individuals with special needs

Corresponding Author: Ersen Yazıcı in

email: ersenyazici@gmail.com

* This study was produced from the first author's Master's thesis supported by Aydin Adnan Menderes University Scientific Research Projects Coordinator with the project number EĞF-17001.

Citation Information: Göktaş, O. \& Yazıc1, E. (2020). Effectiveness of teaching mathematical problem-solving strategies to students with mild intellectual disabilities. Turkish Journal of Computer and Mathematics Education, 11(2), 361-385. 
to acquire independent living skills and take a place in society, it is needed to create appropriate educational environments and training programs. This task is now conducted under the responsibility of the state. However, other people in the society can favor the lives of individuals with special needs by exhibiting positive attitudes and behaviors in particular. Education and training activities towards students who need special education are carried out under the regulations and education programs issued by the Ministry of National Education (MoNE). Students who need special education such as the intellectually disabled, hearing impaired, visually impaired, and physically disabled study at different institutions, based on their needs. In this respect, students with intellectual disabilities are educated in various institutions (such as special education needs practice schools- ${ }^{\text {st }}$ level; special education needs practice schools- $2^{\text {nd }}$ level and special education needs vocational schools- $3^{\text {rd }}$ level) based on their classification. Students with mild intellectual disabilities study at special needs education vocational schools. These students' curriculum includes courses such as Turkish, Mathematics, Social Life, Religious Culture and Moral Knowledge, and personal professional development within the scope of academic skills courses. Mathematics is of significant importance in these courses. These students need mathematical skills in daily life, such as math operations skills, problem-solving skills, reasoning, discovering, calculating, just like their peers with regular education. In our developing and changing world, problem and problem solving will continue to endure as long as humanity exists. It is inevitable that students with intellectual disabilities, too, confront similar problems in everyday life. For this reason, children with intellectual disabilities should receive an education appropriate to their particular needs to be able to live independently within the community. In terms of the learning process, students with mild intellectual disabilities may have slower learning speeds than their peers. They may, however, contribute to production based on their actual performance. "Problem-solving in mathematics is the process of conducting research with controlled trials for the result, which, despite there is a process planning from the beginning to the end, is not immediately reached" (Altun, 2008, p. 58).

According to Polya (1962), problem-solving means achieving a goal that is not immediately reached, overcoming difficulties, and finding a way to get rid of obstacles. It is an exceptional achievement of intelligence, and this intelligence is a special gift endowed on humans. Most characteristically, problem-solving can be considered a human activity. The aim of problem-solving is to understand the problem-solving activity, propose tools for teaching problem solving, and eventually improve the reader's problem-solving ability (Polya, 1962).

In a math course plan prepared for students with mild intellectual disabilities, it is aimed to provide students a way of thinking that will help them solve the problems they will encounter in life. To solve math problems, students need to acquire the concepts related to numbers and operations and become skillful at perceiving the relationship between numbers (Ministry of National Education [MoNE], 2018). Besides, the general objectives of the program include the phrase "he/she gains the problem-solving skills" (MoNE, 2018). Accordingly, students with mild intellectual disabilities should inevitably use some problem-solving strategies to solve their math problems. When considered the methods applied to solve the mathematical problems of these students, it is seen that the strategies based on mathematical operations were mostly used.

While problem-solving skills and problem-solving processes are highlighted in the course plan, there are relatively few studies in the literature that focus on problem-solving processes of students with intellectual disabilities (Barrett, 1995; Casner, 2016; Cihak, 2010; Davis, 2016; Harris \& Graham, 1992; Karabulut, 2015; Kot, 2014; Nar, 2018; Rumiati, 2017; Tufan, 2016). Thus, this study has concentrated on the impact of teaching mathematical problem-solving strategies for students with mild intellectual disabilities studied at special needs education vocational schools on problem-solving skills. In this research, the teaching of problem-solving strategies was conducted through course plans prepared in line with the problem-solving process set out by Polya.

"A problem-solving strategy may not be applied to all problems in every step of the process. Some students may use one strategy very well, while others may implement many of them successfully" (Baykul et al., 2010, p. 16). Therefore, it is of great importance to find out to what extent students with mild intellectual disabilities can learn and use problem-solving strategies. The aim of this study is, by taking into account Polya's (2017) problem-solving steps in mathematics, to teach understanding the problem, generating strategies for solving the problem, using these strategies and checking the result, to the students with mild intellectual disabilities in special education schools, by using the direct instruction method; and then to find out the impact of teaching problem-solving strategies to students with mild intellectual disabilities on their success in problem-solving in mathematics. Literature on problem-solving for individuals with intellectual disabilities generally focus on a single strategy (Schema-based problem solving, self-monitoring strategy, "understand and solve!" strategy, concrete/semi-concrete/abstract teaching strategy, ten cards, abacus, finger counting strategy, and Touchmath) (Can-Çalık, 2008; Casner, 2016; Cihak, 2010; Karabulut, 2015; Kot, 2014; Nar, 2018; Rumiati, 2017; Tufan, 2016; Tuncer, 2009). This study, however, has focused on three problem-solving strategies (intelligent guessing and testing; making a drawing; and working backwards) that students with intellectual disabilities can learn, implement, and are considered to be appropriate to their level. 


\subsection{Conceptual Framework}

Individuals with intellectual disabilities are people who experience severe difficulties in learning and fulfilling the daily life activities, whose intelligence quotient is below two standard deviations, and who have limitations in adaptive skills as well as mental functions (American Association on Mental Retardation [AAMR], 2002). Limitations in adaptive skills are interrelated with limitations in intellectual functions. In order to speak of limitations of an individual, there must have limitations in at least two of the ten skill areas (communication, self-care, home life, social skills, social usefulness, self-management, health and safety, functional academic skills, leisure time, and work). These skill areas lie at the heart of sustaining a successful life. A significant part of the special educational needs of people with intellectual disabilities is closely related to these skills. These skills may differ based on chronological age (Eripek, 1998, p. 39-40). The significant proportion of the intellectually disabled are children and young people who display a slight degree of mental retardation compared to their peers. In the Diagnostic and Statistical Manual of Mental Disorders (DSM-V), published by the American Psychiatric Association (APA), mental retardation is defined as intellectual disability and classified into four groups. This classification, however, has not been made based on IQ scores but on adaptive behaviors. The severity levels of intellectual disability are classified as mild, moderate, severe, and profound. In determining severity levels, the levels of ability to apply vital skills under the titles of the conceptual domain, social domain, and practical domain are considered (American Psychiatric Association [APA], 2013).

An individual with a mild intellectual disability is "the individual with a limited need for special education and general education services due to a mild level disability in mental functions and conceptual, social and practical adaptation skills" (Metin \& Işıtan, 2017, p. 161). "Children in this group usually study at special education classes within regular education schools. These students are allowed to receive education in general education classrooms by offering counseling services to classroom teachers or giving support services to students. Children with a mild intellectual disability may not be recognized until they start school or even they reach the upper classes. It is very likely, however, that they are identified in further classes since the tasks expected from them in school and following courses become more challenging" (Eripek \& Batan, 2016, p. 252). This situation results in students being noticed late and deprived of special education services. It is common for children with mild intellectual disabilities to attend primary and secondary school special education classes. Nevertheless, when they reach the age of secondary education, they face the problem of the fact that there are not a sufficient number of secondary schools with special education classes. Therefore, these students continue their education in special education high schools for mild intellectual disabled under the Ministry of National Education (MoNE) to be able to spend their high school years more efficiently.

There are available programs prepared for children with mild intellectual disabilities. Many children with mild intellectual disabilities can benefit from general education programs. In case support services are provided in general education programs, special education programs are not needed for these children. "There are three groups of models for them. These are the life-centered model, the process teaching model, and the academic model. The life-centered model is the model that aims to improve the life skills of individuals with intellectual disabilities. The process teaching model is the model in which mental functions are attempted to be improved. The academic model is the model that students with mild disabilities are mostly exposed. In this model, the development of academic skills such as reading and mathematics, is targeted" (Sucuoğlu, 2016, p. 236). In general, MoNE's math education program of secondary education students with mild disabilities should aim to enable students to gain the ability to generate new ideas to acquire problem-solving skills throughout life. The educational environment of the students must be compatible with their lives to gain this ability. It is also essential that the educational environment and programs be appropriate to the students' living conditions and mental capacities. Students with mental learning disabilities experience difficulties in learning abstract concepts. Therefore, during the teaching of the basic concepts and principles of mathematics to these students, it would be better to work on more concrete examples, and examples from their immediate circle should be chosen in teaching. Depending on the students' performance, opportunities allowing students to think abstractly should be offered with examples, from concrete to abstract and from close to far. It is suggested that, in order to achieve problem-solving skills in mathematics, students need to be able to understand the relationship between numbers and operations and to have the skills required in the steps of problem-solving (MoNE, 2018).

If the problem is considered as cases that confuse the mind and make the belief uncertain, then solving the problem would be to eliminate ambiguous situations (Baykul, 2014, p. 68). Solving the problem is a practical art like swimming, skiing, or playing the piano. You can learn it by imitating and doing practice only. If you want to learn to swim, you need to jump into the water; and similarly, if you want to become a problem solver, you need to solve problems (Polya, 1962, p. 9). "Problem-solving means knowing what to do in the face of a problem that arises. The problem-solving is described as the process in which steps to be taken and which activities to be performed are clearly defined, and in which research is conducted in a controlled manner to achieve the goal" (Altun, 2008, p. 58). "The problem-solving ability, when faced with a problem, is to understand the problem by 
grasping its content, to choose the appropriate solution for solving the problem, to improve to apply this solution and the ability to interpret the outcomes of the solution" (Baykul et al., 2010, p. 13).

"There is no standard way or method used in the solution process for all problems. If this were the case, the problem would have been solved forever" (Altun, 2008, p. 60). Another essential aspect that is seen consistently during the implementation of problem-solving activities is that the students pay attention to the solutions of the problem and the process of achieving their solutions. This challenges the idea that when studying a problem, students' main focus is to find the solution. Paying attention to the process allows students to analyze the qualities of various solution methods, compare them, and look for applications and extensions of the problem. Solving a problem is the starting point for initiating new mathematical thoughts. Students are, therefore, encouraged to work on diverse problems and look for connections and extensions of the original problem (Santos-Trigo, 1998, p. 639). Understanding the problem process, exploring how the problem is solved, and eventually achieving the result, is very meaningful for the student to learn problem-solving. If the student receives a result-oriented education, he/she will never wonder how to solve the problem, and the teaching will not go beyond memorized solutions. In order for the student to be able to configure the information and to reflect the education he/she received in problem-solving to the solutions of other problems, the student needs to internalize and adopt the problem-solving process thoroughly. Therefore, the way or ways we will follow in the problem-solving process should be consistent in terms of both scientific and pedagogical and should also be supportive of each other.

Polya's problem-solving process is a method that proved itself in the math community, both in the scientific and educational sense. The problem solver must first understand the problem and see what is asked in the problem clearly. In order to understand the problem, he/she needs to analyze the given and asked ones about the problem and find the relationship between these two. In the second step, it is needed to see how the unknown is related to the given ones to have an idea of the solution and ultimately to create a solution plan. The problem solver must make a plan based on the data of the problem and the asked ones. Thirdly, he/she must implement the plan. In the final step, he/she must review and check the solution by going back to the solution completed (Polya, 2017, p. 5).

A problem-solving strategy in mathematics is the method preferred to determine the steps to take and how to solve a problem in order to find a way to be followed in solving a problem. The strategy through which the problem solver intends to solve the problem becomes the strategy he/she chooses and will be his/her own method. In the problem-solving process of Polya, there is a choice of strategy in the planning step. Some of these strategies can be listed as follows: (1) Intelligent guessing and testing (including approximation), (2) solving a simpler analogous problem, (3) animation and simulation, (4) working backwards, (5) finding a pattern, (6) logical reasoning, (7) making a drawing (visual representation), (8) adopting a different point of view (Posamentier \& Krulik, 1998). In addition to these strategies, Baykul et al. (2010) also states: (9) model examination, (10) making tables, (11) organizing a systematic list, (12) writing equations, (13) trial-and-error, (14) elimination, and (15) examining the known ones critically.

In the study, a guessing is made with the intelligent guessing and testing strategy from the problem-solving strategies that are taught to students with mild intellectual disabilities. If this guessing is a logical one, then it enables the solution to be achieved. Even if the guessing is a failed one, it will help to be closer to the solution. Because after the failed guessing, a new idea comes out to reach the solution, thereby helping to get a better understanding of the problem and bringing it closer to the solution. At the end of each guessing, the solution to the problem is now more close, and then the result is achieved (Baykul, 2014, p. 72). The shape/schema/diagram created in the strategy of making a drawing make the problem easier to understand, allow the problem to be perceived as a whole, as well as help in finding a way for the solution. The shape means achieving the solution of the problem with visual elements by establishing a visual connection between the given and asked ones in the problem (Baykul, 2014, p. 73). Instead of the beginning part, sometimes the result of the problem is given in some problems; in this case, the first part is asked. For the solution of such problems, one can go from the result of the problem to the beginning by using the working backwards strategy. "In this process, it is tried to get the first data step by step and to solve the problem by reversing both actions and operations" (Altun, 2008, p. 86).

\section{Method}

In this study, the teaching experiment methodology, one of the qualitative research models, was used to examine the effectiveness of teaching performed with problem-solving strategies in gaining problem-solving skills to students with intellectual disabilities. The teaching experiment pattern can be described as a conceptual tool that researchers use to organize their own activities. Although it is derived from Piaget's clinical interview technique, the teaching experiment is more comprehensive than the clinical interview, as it involves the revelation of the students' mathematical knowledge as well as experiencing the ways/means and situations in which this knowledge is affected (Steffe \& Thompson, 2000). Whereas the clinical interview targets at understanding the student's current knowledge, the teaching experiment aims at understanding the improvements 
that students achieve at the end of an extended period. The teaching experiment consists of four sections. The first one is the teaching stage, the second is the researcher or teacher, the third is one or more students, and the fourth one is the observation of the teaching process and the video recording of all the stages in this process (Steffe \& Thompson, 2000). In the preparation of course plans and teaching process in the implementation stage of the teaching experiment model, the direct instruction method, which is used in special education, has been preferred.

Direct instruction is a method that Engelmann (1998) developed while teaching his own children in the 1960s, and that he tested and revised by working on thousands of students. Direct instruction involves three main elements. These are; the planning of the teaching, the techniques applied in the process of the presentation of the teaching, and the regulation of the teaching. The attitude towards the fact that almost all students can learn mathematics lies directly at the nature of teaching (Polloway, Serna, Patton \& Bailey, 2014, p. 211). "The direct instruction method consists of three stages: becoming a model, guided practice, and independent practices. Teaching practices are conducted by the guidance of the teacher" (Bağlama, 2018, p. 30).

In "becoming a model," which is the first stage of direct instruction, the teacher is actively becoming a model to the student. At this stage, the teacher is at the position of directly undertaking the teaching of the subject, whereas the student is at the position of observing and listening. The second stage, called the guided practice, is the stage where the teacher acts as a guide and the student themselves actively participates in the process. The student is now gradually involved in teaching and starts to make progress. This process is essential for direct instruction. In the third stage, namely independent practice, the student is expected to make his/her own decisions for the solutions of the subject that is being taught. This practice has to be made ingeniously every time. In order for the student to reach this level, the step of "becoming a model" and the step of guided practice must be explained meticulously by the teacher to the student, together with tips, technological support, and abundant educational materials (Engelmann \& Carnine, 1991).

\subsection{Participants}

One of the purposeful sampling techniques, criterion-sampling, was used to determine the participants. To this end, nine possible participants with mild intellectual disabilities who study at the Special Needs Education Vocational Schools under the Ministry of National Education (MoNE) were administered a reading comprehension test, a math operations test, and a problem-solving test developed by the researcher. These instruments were developed and then used in line with the views of Turkish field experts, special education field experts, and mathematics field experts. By evaluating the responses of the students to the mentioned measurement instruments and the teacher's views, the student group to which the problem-solving strategies were taught was determined. As the selection criteria for students, achieving success of at least $75 \%$ from the reading comprehension test, gaining success of at least $50 \%$ from the math operations tests involving in-hand addition, subtraction with borrowing, multiplication, and division, and solving at least two of the five problems comprising at least one operation in the problem-solving test were determined. The participant group of the study was created by selecting three students, who met the criteria among nine students, who were voluntary and suitable for working conditions, of a special needs education vocational school that provides education to students with mild intellectual disabilities in a city center in Aegean Region in the 2018-2019 academic year. Of the special education high school students who were selected regardless of the gender, three students, two of whom are male and one is female students, are in the age range of 15-18 and suitable for the requirements. When evaluated the condition of the students' meeting the criteria, it can be stated that the three selected students were generally able to solve problems, use different strategies though they were not taught, were more advanced in understanding the problems they read than other students, and were keen to participate in the study. According to hospital health board reports and data obtained from counseling and research center, Student T's Stanford-Binet Intelligence Test Score (IQ) was 63, diagnosed with F-70 mild mental retardation, and the total loss of body function was 50\% according to the condition of inability. Student M's Stanford-Binet Intelligence Test Score (IQ) 61, diagnosed with F-78 mild mental retardation, and total loss of body function was $50 \%$ according to the condition of incapacity. Student K had a WISC-R SIQ58-PIQ70-TIQ62 test score, with a mild mental retardation + clinical epilepsy diagnosis, and total loss of body function was $53 \%$ according to the condition of inability.

\subsection{Data collection tools}

The research data consists of the answers given by the students to the problems in Stage 1 and Stage 2 of the independent practice of the course plans prepared by the researcher according to the direct instruction method, and the transcriptions of the images reflected in the video recording at this stage. Follow-up forms prepared and then given to students have been a complete source for data by combining them with video transcriptions. During solving each problem, the student received training by using the follow-up form and then applied it. The use of the follow-up form is an activity chosen for the student to internalize the process thoroughly. 


\subsection{Data analysis}

A descriptive analysis was used in data analysis. "With this analysis, findings identifying the individuals taught are evaluated. With content analysis, data determined as being similar and related to each other are interpreted by combining them within the framework of certain concepts, themes, and codes" (Karataş, 2017, p. 79). "The descriptive analysis comprises four stages (Yıldırım \& Şimşek, 2008, p. 224): (1) Creating a framework for descriptive analysis, (2) Processing the data according to the thematic framework, (3) Defining the findings, and (4) Interpreting the findings". In creating the themes in this study, Polya's (2017) problemsolving steps such as, understanding the problem, making plans, and implementing the plan, were determined as the main themes. By encoding under these themes, findings were constructed compatible with these encodings.

To ensure the encoding reliability, a field expert of special education, apart from the researcher, was designated as the encoder. Encodings were made only for independent practice stages (Stage 1 and Stage 2). Encoders encoded research data independently from each other. All resulting codes were classified as "analogous codes" and "decomposing codes." Miles and Huberman (1994) refer to analogous codes, "consensus," and decomposing codes as "dissensus," and propose the formula of "Consensus / (Dissensus + Consensus) x 100" for the interrater reliability. Within the scope of the study, the percentage of Miles-Huberman compliance was found 0.80 , according to the above formula. This value is considered as a sufficient level in terms of encoding reliability.

In line with the views of the field expert of special education, the follow-up form was used in all stages of the course plans up to Stage 2 of the independent practice. With this form, both the learning processes of the students were kept under control, and the identification of codes became more manageable during the data analysis. It can be stated that the use of the follow-up form enhances encoding reliability. From the general data collection methods, participant observation, document review, and the transcription of the interview conducted with the student by taking a video recording were used during the teaching process of the research in creating data. Thus, it was attempted to find out how participants perceived, conceptualized, and evaluated the teaching. In addition to the existing data collection methods, it was tried to increase the validity and reliability of the research by diversifying the data through the video recording method, one of the supportive data collection methods.

\subsection{Process}

In this study, the teaching of three strategies (intelligent guessing and testing; making a drawing; working backwards) was determined. In the selection of these three strategies, it was preferred that the strategies did not require much logical reasoning, writing equations and complex operations. After the strategies were determined, course plans were prepared for each strategy in line with the direct instruction method (motivating the student, becoming a model, guided practice, and independent practice). Eighteen of the problems in the course plans prepared with the direct instruction method were initially drafted by the researchers. On the other hand, six of them were inspired by the problems mentioned by Posamentier and Krulik (1998). All problems were submitted to the approval of experts in the field of mathematics education and special education and then applied by making the necessary corrections. The first course plans were prepared comprehensively, one for each, and submitted to the approval of experts in the field of mathematics education and special education. The content and teaching of the problems were corrected in line with the views of the expert having mathematics education. Because the students are special education students, a follow-up form in line with the views of the field expert of special education was developed for the students to be used in model practice, guided practice, and independent practice steps in the teaching process. During solving each problem, the student received training by using the follow-up form and then applied it. By incorporating the follow-up form into the teaching process, the independent practice was increased to two stages, and two evaluations were carried out as Stage 1 and Stage 2. While the student was allowed to use the follow-up form in Stage 1, for the evaluation in Stage 2, the student was asked to perform a completely independent practice on a blank A4 paper without being given the follow-up form. In each strategy course plan, eight problems were taught and solved, including 4 for each. A total of 24 problems from three strategies were studied. Before teaching with the participant group, a pilot scheme was performed with another non-participant student, and re-evaluations were carried out, and preparations for the original participant group were made. A course plan for each strategy was planned to be $5 * 40$ minutes, and the teaching of students was conducted in the way of one-to-one training in a classroom environment. Each course plan took a week and a half to implement. The whole teaching process was recorded with a video camera. After each step, the student's follow-up form and A4 answer sheet were filed. Materials used in different teachings are hanging on the walls inside the classroom. The necessary documents were introduced by the researcher while teaching the students. The teaching was performed on the whiteboard with the support of a projector. There are desks and seats for students to sit on, as well as a teacher's desk. During the lessons, the student was placed on the teacher's desk and seat in the classroom, facing the whiteboard. The camera was placed in a way to see the board while the researcher was teaching during the model application step. In the guided practice, the researcher placed a chair next to the student's desk and sat side by side with the student. At this time, the camera was placed 
in a way to see both the student and the researcher as well as the working sheet. In the independent practice step, however, the researcher was standing, and the camera was positioned next to the table in a way to see the student and his/her paper.

\section{Findings}

The findings of the study regarding the three problem-solving strategies are provided under the main headings. The first of these strategies is the intelligent guessing and testing strategy, the second one is the strategy of making a drawing, and the third one is the working backwards strategy. The findings were explained by evaluating the performances that each student displayed according to the main themes and encodings. Three different strategies were evaluated within itself, and the findings of the students were presented under the title of strategies.

When evaluated the findings of the intelligent guessing and testing strategy in general, it has been observed that the students tried to create the steps of the given and asked ones after reading the problem. At this stage, except for Student T, the other students correctly created these steps. It was seen that Student T directly engaged in the problem to solve, without looking at the given ones. On the other hand, Student T understood the given part as "Of which concepts have we been given information in the problem?" Student $\mathrm{T}$ did not feel the need to write the values of these concepts. It was witnessed that Student $\mathrm{T}$ created the asked ones together with the given ones, as if he/she had to find the values specified in the given ones that he/she was not actually required to study. Student T used the expression "I will draw a table for my guessing," indicating that he/she chose the intelligent guessing and testing strategy for solving the problem. It was observed that he/she created his/her table and titles correctly, but instead of solving the problem on the table, he/she started to solve the problem on a separate A4 paper sheet. Rather than using the intelligent guessing and testing strategy for solving the problem, it was seen that he/she tried to reach the solution by using the extreme cases that had not been taught before, and by reasoning, which he/she was able to do on his/her own. It was observed that the student started to solve the problem by steps compatible with the intelligent guessing and testing strategy. However, when he/she advanced to the solution process, he/she preferred to solve the problem with a different strategy. He/she was able to solve the problem without having any difficulties in using extreme cases and implementing reasoning strategy. After thinking that he/she reached the result of the problem, he/she achieved his/her guessing by doing mathematical operations in mind, by also writing the results he/she got in the prediction section on the table. It was observed that the student solved the problem with the intelligent guessing and testing strategy as well.

It was seen that the students were generally successful in the step of understanding the problem, one the problem-solving steps of Polya. It was witnessed that in all problems, the students were able to draw a table for the guessing of the strategy by selecting the intelligent guessing and testing strategy. Student M had difficulties in creating the table title in the first applications, but other students were, in general, able to create the table titles. It was observed, however, in the last applications that Student M, too, could create the table titles. This indicates that the students were able to benefit effectively from the table in using the intelligent guessing and testing strategy. It was seen that in the problems of which the teaching and evaluation were made, they were able to make predictions in accordance with the strategy in general. They were observed to control the guessing results by comparing the results of their guessing with the given. In the problem in which there was an additional criterion, all students were seen to get stuck on the criterion and not able to implement the strategy. It was discovered that the number of the guessing of the students who could not see the systematic correlation between their guessing increased, and they became perplexed, so they could not use the strategy in tune with its nature. Therefore, within the framework of the findings of the research on intelligent guessing and testing strategy, it was determined that students could run this strategy for problems that do not contain complex criteria, and that if there was a criterion, however, that determines the relationship between variables, they would experience difficulty. Sample images from the student's answers about the solution process are shown in Figure 1. 


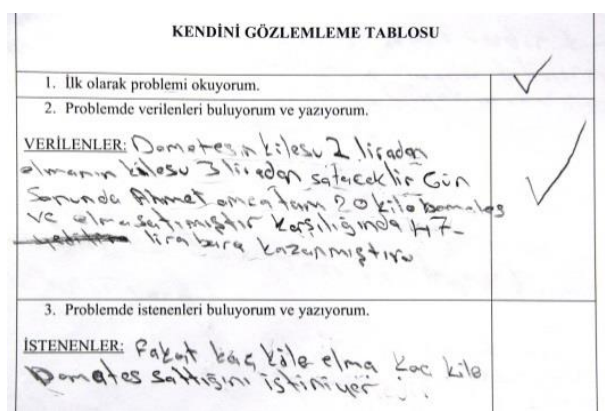

a) Student $T$, the given and asked ones

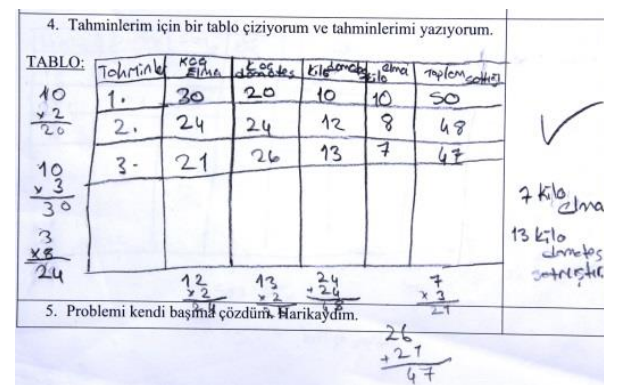

b) Student M, creating table titles

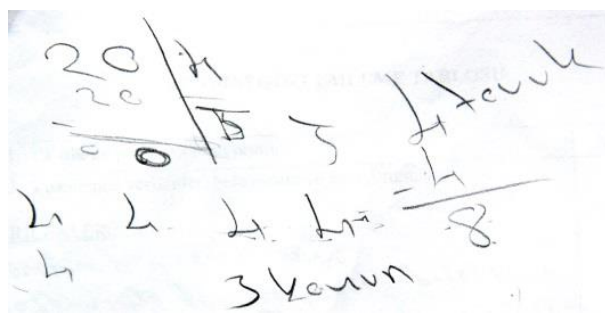

c) Student T, the strategy of using extreme cases

Figure 1. Sample images from the student's answers on intelligent guessing and testing strategy

When the findings of independent practice on the strategy of making a drawing were evaluated, all students, except for Student T, were observed to be generally successful in creating the given and the asked ones of the problem. It was also found that Student $\mathrm{T}$ often wrote incomplete information since he/she did not read the question very carefully when creating the given ones. All students were seen to be able to choose and implement the strategy of making a drawing to solve the problem. During the implementation stage, it was seen that they could draw shapes compatible with the given ones of the problem. If there were more than one criterion and instruction in the problems, it was observed that students got stuck on these criteria and instructions at different rates. They were seen to be unable or have difficulty implementing the strategy due to these pauses. However, they were able to perform the criteria with the guidance of the researcher. It was found that, although one of the students had much more difficulty applying the criteria or even failed to do that, another student succeeded without having any trouble. It was observed that students could, in general, reach the solution results of problems directly by performing operations with rhythmic counting, making mathematical operations in mind, or without performing operations using a shape. The individual differences of the students seemed to lead to considerable differences in the implementation of the strategy. Nevertheless, in general, the students were seen to understand the nature of the strategy and to be able to put it into practice. At the points where they had difficulty implementing the strategy for various reasons, they were observed to succeed with the guidance of the researcher. Sample images from the student's answers about the solution process are shown in Figure 2.

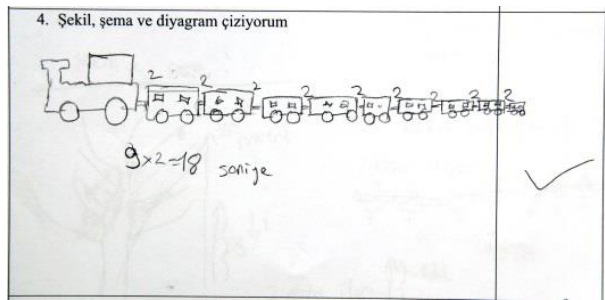

a) Student M, making a shape according to the context

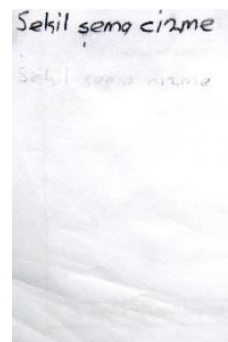

b) K student, getting stuck on the criterion
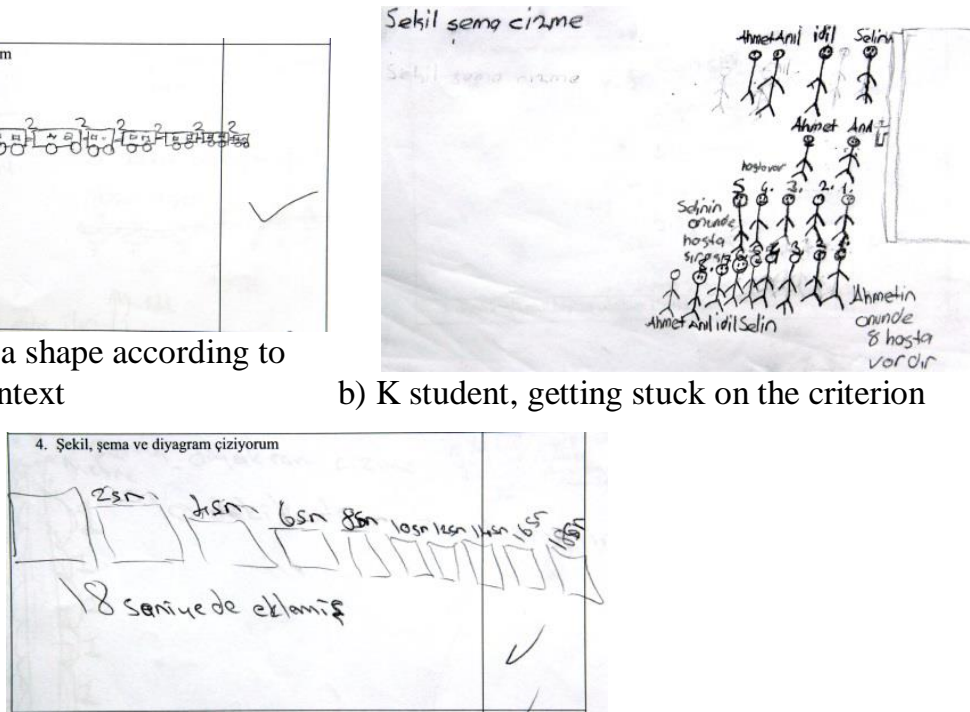

c) Student T, making a shape according to the given ones

Figure 2. Examples of the student's answers on the strategy of making a drawing 
The findings of the working backwards strategy, in general, indicated that all of the students were successful in creating the given and asked ones. It was observed that all students chose and tried to implement the strategy that was taught in order to solve the problem. In solving the problems, they were seen to be able to use the strategy of making a drawing that they had learned before, as well as the working backwards strategy. Although it seemed difficult for students at first to move backward from the most recent given to the first given one in the problem, they were observed to have no difficulty going backward as the number of problems studied soared. They were seen to have difficulty going backward when the type of problem they solved was altered, and they were more successful in the type of problem which they did many exercises. It was observed that if the problems contained a criterion, the students had difficulty implementing the working backwards strategy, and they were even sometimes unable to use it. At this stage, almost all students needed the guidance of the researcher, and they were seen to be able to implement the strategy with the guidance only. However, if they understood the criterion, they had no difficulty implementing the strategy. Sample images from the student's answers about the solution process are shown in Figure 3.

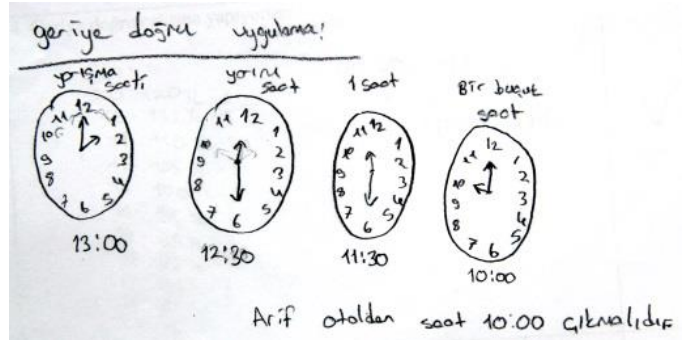

a) Student M, using two strategies together

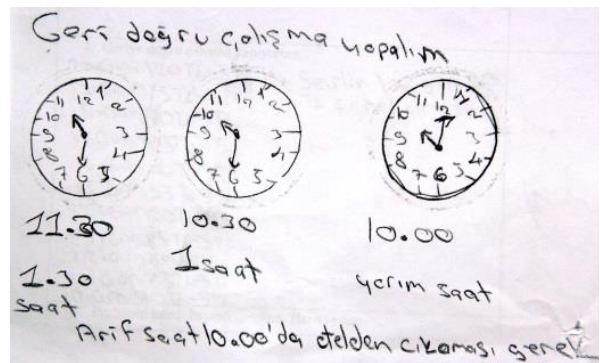

b) Student T, using two strategies together

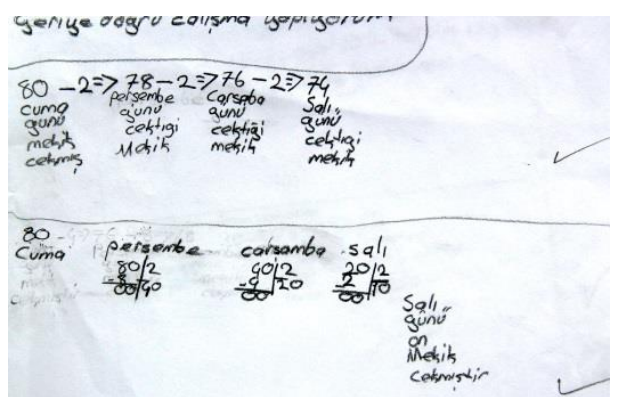

c) Student K, getting stuck on the criterion

Figure 3. Examples of the student's answers on the working backwards strategy

\section{Discussion}

It was reflected in the preliminary findings of the study that the participant students with mild intellectual disabilities had limitedly implemented the strategies in the problem-solving process before they had received an education; however, the findings of the study have indicated that they started to use strategies more and more effectively after the teaching of strategy. Similar to the contribution made to the academic achievements of the students mentioned in the course programs, it can be understood from the research findings that the teaching of problem-solving strategies, which are relatively more difficult to develop, has also played a useful role in improving their skills. Barrett (1995) examined in his research the possible differences in problem-solving abilities between children with intellectual disabilities and regular class children. It has been found that children with intellectual disabilities and regular class children of comparable developmental level (mental age) employ much the same problem-solving strategies and have similar solution time rates when involved with problem solving of game-like tasks. Similar to Barrett's (1995) study, it can be stated that the performance of students with mild intellectual disabilities in the problem-solving process reflected in the findings of our study overlaps with the study results in the literature conducted on the problem-solving processes of children with typical development (Aydoğdu \& Yenilmez, 2012; Baykul et al., 2010; Turhan, 2011). The operations, calculation errors, and ways of using strategy used by students with mild intellectual disabilities in the problem-solving process bears a resemblance to those of children with typical development that are comparable and appropriate to their level.

It has been observed in the problem-solving process that students made use of mathematical operations, rhythmic counting operations, mathematical operations skills such as addition, subtraction, multiplication, and division, as well as performing math calculations in mind. It has been seen that, although students with mild intellectual disabilities exhibited the mentioned behaviors based mostly on operational skills to a certain extent, they had difficulty performing higher-level skills, such as logic, writing equation, reasoning, and complex 
operations than their peers with typical development and could not use them effectively in problem-solving. The reasonable explanation of this is that, during the teaching of mathematical operations skills to students with mild intellectual disabilities, a large number of examples were provided with an algorithmic approach (according to the order of operations) based on errorless teaching methods. It is believed that the students' learning of order of operations, which is the basis of this teaching, bears a resemblance to rote learning. What is expected from students, is to be able to perform operations with the algorithmic approach in problems that require four operations. Due to their special needs, the students are not anticipated to be able to perform operations that require high-level skills as much as operations skills. In the research of Temizöz (2013) on problem-solving regarding students with intellectual disabilities, the participant students were observed to follow mainly operational knowledge, rather than conceptual one, in mathematical problem-solving. The study has concluded that students with mild intellectual disabilities tend to use operational skills in general, yet it should not be overlooked that they tried to use problem-solving strategies by moving away from using direct operational skills at the end of strategy teaching. Based on both the informal observations of the researcher and the students' problem-solving papers, it can be concluded that the three participant students have changed their thinking that problem-solving in mathematics does not just consist of mathematical operations; moreover, different ways can be used to solve the problem and even more than one strategy can be implemented to solve the same problem.

In the teaching process of the research, Polya's problem-solving steps were implemented, which are also used in the problem-solving process of children with typical development. When the findings of the research are evaluated according to Polya's problem-solving steps, it is concluded that the students were not able to fully display some behaviors (Polya, 2017), such as identifying the given and asked ones, and explaining the problem, which is considered to be critical behaviors of the step of understanding the problem in the first courses of strategy teaching. Besides, they were unable to proceed in solving some problems and often returned backward to understand the problem to solve it. The most fundamental challenge students experienced in understanding the problem stems from reading comprehension (Baykul, 2014). This situation is also the same for children with typical development. At the beginning of the teaching, it was seen that Student T was not successful in creating the given ones of the problem; but at the end of the teaching, he/she began to organize the given ones correctly. It was, nevertheless, observed that the other two students correctly created the given and the asked ones in all the problems, from the beginning to the end of the teaching. The possible reason that Student $\mathrm{T}$ was not successful in creating the given ones at the beginning of the teaching may be that there was no teaching on understanding the problem in a way that indicated the given and asked ones; but rather, that the teaching focused on solving the problem in the teaching on the math problems conducted before the implementation. Because the fact that Student $T$ was successful in creating the given ones towards the end of the teaching applied within the scope of research seems to support this view. As for the behavior of explaining the problem, it has been observed that not all of the students, but at least one of them, could express the problem with their own sentences or explain the solution process. These behaviors may be regarded as an indication that students, in general, have successfully completed the step of understanding the problem at the end of the strategy teaching process. It can be stated that if they complete the step of understanding the problem, they plan to solve the problem and put their plans into practice. It was observed that in advance of teaching, students generally took a problem-solving approach in the way of reading the problem and then referred to mathematical operations without knowing why. However, it was seen that during the teaching process and the independent evaluations made at the end of the teaching, the students made plans by focusing on the teaching strategies instead of just considering performing mathematical operations to solve the problem. This indicates that the three students were able to act appropriately to Polya's plan-making step in problem-solving. It seems that the students controlled the accuracy of any guessing they made in the intelligent guessing and testing strategy, by comparing them with the given ones. However, it was found that all three students had never applied to the step of checking and cross-checking, which is the final step of Polya's problem-solving process. None of the students' problem-solving records presented any indication that they had displayed the behavior of checking or cross-checking the operations they had performed. This finding is similar to the findings of studies over their peers with typical development regarding the problem-solving process (Baykul et al., 2010).

The findings of the study on problem-solving strategies were discussed separately for each strategy. The intelligent guessing and testing strategy is the first strategy that was taught within the scope of research. Therefore, students are considered to suffer from inexperience in the first stages of teaching. It has been found that they had difficulty implementing the first course plan but were then able to adapt to the teaching process. In all independent assessment steps, where problems are anticipated to be used in the intelligent guessing and testing strategy, all of the participant students seemed to have learned the nature, functioning, and way of using the strategy. In general, students were able to choose intelligent guessing and testing strategy to solve the problem and create a table to implement the strategy. It has been observed that Student M experienced problems with the first applications in creating the table titles they created for their predictions and needed researcher guidance to complete the titles. It can be stated that the guidance looked like a tiny cue and in a way that allowed students to recognize them. It seems from the findings relating to two students that they were able to create the 
table titles accurately. It can be stated that the students made their initial guessing randomly in general; for the later ones, however, they switched to systematic guessing if they understood the given ones of the problem well. It is considered that in case they were unable to figure out the logic hidden in the problem, they continued to make random guessing, thus increasing the number of guessing. Especially when students were unable to understand the problem, they needed researcher guidance to be able to make their guessing. Therefore, it can be pointed out that the step of understanding the problem for students with mild intellectual disabilities is a critical step in the problem-solving process, as is the case for students with typical development. It seems that when reading some of the problems, they did not read the information given in them very carefully, so they missed some information. Student $\mathrm{T}$ and Student $\mathrm{K}$ were observed to be unable to advance to the guessing step because of the difficulty they had in understanding the problems, and that the number of guessing considerably increased because they made calculation errors at the stage of testing the accuracy of their guessing. It can be stated that this situation made the students more confused and lead to serious challenges in achieving results. It has been concluded that they could not solve the problem without the guidance of the researcher in such cases.

Remarkably, Student T applied to "the strategy of considering extreme cases and logical reasoning" in solving a problem that was not taught before, as well as the strategy of teaching. This indicates that the student surprisingly did not hesitate to choose and implement his/her own problem-solving strategy in the problem. The student solved the problem with his/her own preferred strategy and reached the right conclusion. This shows that the student does not believe that a problem needs to be solved with just one strategy, but rather, thinks that more than one strategy can be used for achieving the solution. In his research, Çelebioğlu (2009), which examined the levels of primary school first-grade students to be able to use problem-solving strategies, reported that first graders were able to use strategies even though they had not been taught. This finding is similar to that of Student T being able to use the "strategy of considering extreme cases," even though he/she was not taught.

In the final independent question of the practice of the intelligent guessing and testing strategy, all of the students experienced a similar process. It has been observed that an additional second criterion in the problem places a particularly high burden on the students' implementation of the strategy. Both the content of this criterion and the fact that it created additional instructions caused the students to fail in implementing the strategy. The students' facing with the criteria in the problem such as "solid, more, missing, half, and having more than one instruction in the problem" has been assessed as a situation that the students did not encounter much before, and also they were seen not to know what to do in solving such problems. As a result, students have been observed to not be able to to deal with this criterion on their own, they could not use the strategy in this case but were able to solve the problem with the researcher's guidance.

The strategy of making a drawing can be considered to be the most successful one for all three students. This is because the students were successful both in choosing the strategy and in making a drawing appropriate to the problem. In particular, the fact that the drawings of Student $M$ were compatible with the context of the problem is remarkable. Similarly, among the drawings of Student $\mathrm{K}$ are the drawings appropriate to the context of the problem. It can be stated that when making a drawing in the problem, Student $\mathrm{T}$ preferred symbolic shapes that were appropriate to the given of the problem, instead of struggling to draw shapes that are appropriate to the context of the problem. Besides, it seems that the shapes drawn by all three students reflect the given and asked ones of the problem. While students were able to draw shapes in problem-solving, it has been witnessed that when they faced the additional criteria in the problems, they experienced difficulty and could not progress without guidance. Student K was observed to get stuck on the criteria for the second, third, and fourth problems, and to have difficulty in overcoming these criteria and not to be able to solve them without the researcher's guidance. The fact that the student experienced the same challenge in all three questions brings to mind that this may be due to the individual differences of the student. It is also likely to state that all three students experienced difficulty with the additional criteria in the problems.

The findings of the working backwards strategy have indicated that all three students were able to select the strategy and then begin the stage of implementing the strategy. It has been observed that for all problems, Student K had difficulty applying the working backwards strategy. It seems that Student K mixed up the places to go, confused the times to go back, and, in the final problem, got stuck on the criteria and was only able to move forward with the researcher's guidance. In the working backwards strategy, Student K could express the need to follow a backwards way based on the given ones, but could not implement it. It is thus believed that Student K grasped the nature of the working backwards strategy, but was not successful in implementing it. The research findings show that Student K was more successful in using the other two strategies. Student T got only stuck on the criteria in the final problem, one of those related to the working backwards strategies. It is assumed that this issue stemmed from the difficulty he/she experienced in understanding and applying the criterion in the problem. When it comes to other problems, it seems that Student $\mathrm{T}$ was able to implement the working backwards strategy. It has been observed that Student M, too, got stuck on the criteria in the last problem and had difficulty understanding and applying the criteria in the problem. All three students were able to understand the criteria of the final question with the researcher's guidance only. One of the remarkable findings is that 
Student $\mathrm{M}$ and $\mathrm{T}$ drew the clock models and solved the problem on these models, using the strategy of making a drawing that they were taught before, as well as estimating and writing the hours down by operating while solving the problem backwards in their clock problems. This indicates that the students could generalize the strategy they had learned before and used it in other problems as well and implemented the two strategies together. In other words, students were able to use the strategy they have learned in different problems without limiting it to existing ones.

When the findings of the three strategies are considered together, it has been concluded that the three students were able to write the given and the asked ones in the step of understanding the problem and explain the problem with their own sentences when necessary. It has been observed that they were able to determine the appropriate strategy for solving the problem and take steps in this direction. It has also been determined that they tried to make the necessary actions to solve the problem and could explain what they did in the solution process. It is believed that when they fully understand the problem, they can reach the correct result. Nevertheless, if they do not understand the problem, then they need guidance. It seems that if there are additional criteria and further instructions within the problems, students have difficulty solving the problem and even are unable to solve them on their own. It is believed that they should be guided in such cases. Therefore, the problems to be addressed to these students should not include too many criteria but comprise a limited number of instructions. The teaching of problem-solving strategies seems to play an effective role in these three students' problem-solving achievements. Some researchers have also come to similar conclusions, such as; Nar (2018) has proved that the concrete/semi-concrete/abstract teaching strategy is effective in teaching the math operations of addition; Rumiati (2017) has revealed that the use of ten cards and abacuses may be useful for developing strategies for solving addition and subtraction problems of adolescents with mild intellectual disabilities; Casner (2016) has concluded that most of the students involved in the research learned as a result of schema-based teaching and improved their mathematical problem-solving skills; Kot (2014) has stated in his research that the scheme-based teaching strategy conducted by the direct instruction method is effective in the mathematical problem-solving performances of children affected by intellectual disability; Altun and Arslan (2006) have concluded that the environment created for the teaching of problem-solving strategies to primary school students has an impact on teaching some strategies.

\section{Suggestions}

- The results and findings of the research indicate that the teaching of problem-solving strategies to students with mild intellectual disabilities narrows the gap between them and their peers with typical development, and directs them to use different strategies, instead of focusing directly on operational skills in the problems. Moreover, the steps of the problem-solving process lead them to exhibit appropriate behavior. It is thus suggested that teachers of mathematics and special education who work with students with mild intellectual disabilities should try to teach mathematical problem-solving strategies patiently and use systematic approaches similar to Polya's problem-solving process.

- It has been observed that the step of understanding the problem is crucial in the problem-solving process for students with mild intellectual disabilities, just like students with typical development. It is suggested in this step that studies focusing on critical behaviors and aiming just to understand the problem, should be carried out as an indication of the level of understanding of the problem.

- When considered the fact that students with mild intellectual disabilities can develop their own strategies for problem-solving, use any, or several strategies together they preferred, and use one strategy they learned before to solve another problem, teachers are advised to allow students to choose their own strategies and to take measures for teaching different strategies.

- It is suggested that, in the teaching process designed for the problem-solving skills of students with mild intellectual disabilities, the problems to be solved should not include criteria that will confuse the student, and instructions that will cause complexity for the student but should include criteria and instructions that are appropriate to their level.

- In the teaching of problem-solving strategies to students with mild intellectual disabilities, it will be useful to prepare course plans appropriate to the direct instruction method and to benefit specifically from the followup form.

- The teachers are advised to design and implement their course plans in a way to be able to check the students' problem-solving results and improve their ability to cross-check.

It is suggested that problems that will spark the interest of the students, which include examples from everyday life and which the students will be happy to solve, should be preferred in teaching problem-solving. 


\section{Hafif Düzeyde Zihinsel Engelli Öğrencilere Matematiksel Problem Çözme Stratejileri Öğretiminin Etkililiği}

\section{Giriş}

İnsanlar, dünyada var olduğu günden bugüne, yaşamlarını idame ettirebilmek için, doğayla, hayvanlarla, bitkilerle ve hemcinsleriyle sürekli bir mücadele içindedirler. Yaşadıkları bu mücadeleler onlar için çözülmesi gereken bir problem olmuştur. İnsanın bulunduğu her dönemde, her yerde problemler de insanlarla beraber gelmiştir. İnsanlar, bu problemlerin çözümü için, formal veya informal bir şekilde muhakkak eğitim almaktadırlar. Evrensel olarak çocuklar hayata hazırlık amaçlı okullarda eğitime alınmaktadırlar. Ülkemizde eğitim hakkı, anayasamızın "Madde 42 - Kimse, eğitim ve öğrenim hakkından yoksun bırakılamaz" maddesi ile güvence altına alınmıştır. Dünyada ise insan hakları evrensel bildirgesi ile "Madde 261 . Herkes eğitim hakkina sahiptir. Eğitim, en azından ilk ve temel eğitim aşamasında parasızdır. İlköğretim zorunludur. Teknik ve mesleksel eğitim herkese açıktır. Yükseköğretim, yeteneklerine göre herkese tam bir eşitlikle açık olmalıdır" maddesi ile bütün çocuklarımızın eğitim öğretime katılmaları ve desteklenmeleri gerekmektedir. Özel gereksinimli bireylerin bağımsız yaşam becerilerini kazanmaları ve toplum içerisinde yer edinebilmeleri için uygun eğitim ortamlarının ve eğitim programlarının oluşturulmasına ihtiyaç vardır. Bu durum devletin sorumluluğunda olan bir durumdur. Toplumun geri kalanı, özel gereksinimli bireylerin hayatlarını olumlu tutum ve davranışlarla kolaylaştırabilir. Özel eğitime ihtiyaç duyan öğrencilere yönelik eğitim öğretim faaliyetleri, Milli Eğitim Bakanlığı (MEB)'nın çıkarmış olduğu yönetmelikler ve öğretim programlarına uygun bir şekilde yürütülmektedir. Özel eğitime ihtiyaç duyan öğrenciler, zihinsel engelli, işitme engelli, görme engelli ve bedensel engelli şeklinde farklı kurumlarda eğitim görmektedir. Zihinsel engelli öğrenciler, sınıflandırmalarına göre farklı kurumlarda eğitim almaktadır. Bu engel gurubu içerisinde bulunan hafif düzeyde zihinsel engelli öğrenciler ise özel eğitim meslek okullarında eğitim görmektedir. Bu öğrencilerin ders programında akademik beceri derslerinin içerisinde Türkçe, Matematik, Sosyal hayat, Din kültürü ve ahlak bilgisi ve Kişisel mesleki gelişim gibi dersler yer almaktadır. Bu derslerin içerisinde matematik dersinin önemi büyüktür. Öğrenciler hayatın içerisinde gerekli dört işlem becerilerine, problem çözme becerilerine, akıl yürütme, keşfetme, hesaplama yapma gibi matematiksel becerilere normal gelişim gösteren akranlarına benzer şekilde ihtiyaç duymaktadır. Gelişen ve değişen dünyada problem ve problem çözme insanlık var olduğu sürece var olmaya devam edecektir. $\mathrm{Bu}$ nedenle zihinsel engelli öğrencilerin de benzer problemlerle karşı karşıya kalması kaçınılmazdır. Zihin engelli çocukların da toplum içerisinde bağımsız olarak yaşamlarını sürdürebilmeleri için gereksinimlerine uygun eğitim almaları gerekir. Hafif düzeyde zihinsel engelli öğrenciler öğrenme süreci yönünden değerlendirildiğinde; öğrenme hızları akranlarından daha yavaş olabilir ancak var olan performansları doğrultusunda üretime katılabilirler. "Matematikte, problem çözme süreci ise, sürecin başından sonuna kadar planlanmasına rağmen, sonuca hemen ulaşılamayan ve sonuç için kontrollü denemelerle araştırma yapma sürecidir" (Altun, 2008, s. 58).

Polya'ya (1962) göre problem çözme; hemen ulaşılamayan bir amaca ulaşmak, zorluklardan kurtulmak, engellerden kurtulmak için bir yol bulmak demektir. Problem çözme, zekânın özel bir başarısıdır ve zekâ insanlığa sunulmuş özel bir armağandır. Problem çözme, en karakteristik olarak, bir insan etkinliği olarak kabul edilebilir. Problem çözmenin amacı, problem çözme aktivitesini anlamak, problem çözmeyi öğretmek için araç önermek ve sonunda okuyucunun problem çözme yeteneğini geliştirmektir (Polya, 1962).

Hafif düzeyde zihinsel engelli öğrenciler için hazırlanan Matematik Dersi Öğretim Programında; matematik dersiyle öğrencilere yaşamlarında karşılaşacakları problemleri çözmeye yardımcı olacak düşünme yolu kazandırmak amaçlanmıştır. Öğrencilerin karşılaştıkları matematik problemlerini çözebilmeleri için sayı kavramlarını, işlemlerle ilgili kavramları kazanmalarına ve sayılar arasındaki ilişkiyi sezebilme becerilerine gereksinimleri vardır (Milli Eğitim Bakanlığı[MEB], 2018). Bunların yanı sıra programın genel amaçları içerisinde "Problem çözme becerisi kazanır." ifadesi de yer almaktadır (MEB, 2018). Hafif düzeyde zihinsel engelli öğrencilerin matematik problemlerini çözebilmeleri için bazı problem çözme stratejilerini kullanmaları kaçınılmazdır. Bu öğrencilerin matematik problemlerini çözmeleri için uygulanan yöntemler incelendiğinde en çok dört işlem temelli matematiksel işlem stratejisinin kullanıldığı gözlenmiştir.

Öğretim programında problem çözme becerisi ve problem çözme süreçlerine önemle yer verilmesine karşın alanyazında zihinsel engelli öğrencilerin problem çözme süreçlerine odaklanan az sayıda çalışma bulunmaktadır (Barrett, 1995; Casner, 2016; Cihak, 2010; Davis, 2016; Harris ve Graham, 1992; Karabulut, 2015; Kot, 2014; Nar, 2018; Rumiati, 2017; Tufan, 2016). Buradan hareketle çalışmada özel eğitim mesleki eğitim merkezi okullarında eğitim gören hafif düzeyde zihinsel engelli öğrencilere yönelik hazırlanan matematiksel problem çözme stratejileri öğretiminin, öğrencilerin problem çözme becerilerine etkisine odaklanılmıştır. Çalışmada Polya tarafindan ortaya konulan problem çözme sürecine uygun olarak hazırlanmış ders planları yoluyla problem çözme stratejilerinin öğretimi yapılmıştır. 
"Bir problem çözme stratejisi, her aşamada bütün problemlere uygulanamayabilir. Bazı öğrenciler stratejinin birini çok iyi kullanabilir, bazı öğrenciler ise birçok stratejiyi iyi kullanabilir” (Baykul ve ark., 2010, s. 16). Bu nedenle hafif düzeyde zihinsel engelli öğrencilerin problem çözme stratejilerini ne düzeyde öğrenip kullanabilecekleri büyük önem arz etmektedir. Bu çalışmada özel eğitim okullarında eğitim alan hafif düzeyde zihinsel engelli öğrencilerin, matematik dersinde Polya'nın (2017) problem çözme aşamaları göz önünde bulundurularak; problemi anlama, problemin çözümü için strateji üretme, bu stratejileri kullanma ve çözümün kontrolü durumlarının, doğrudan öğretim modeli ile öğretimi yapılarak, hafif düzeyde zihinsel engelli öğrencilerin problem çözme stratejilerinin, problem çözme başarılarına etkisini ortaya koymak amaçlanmıştır. Ulusal ve uluslararası alanyazında yer alan zihinsel engelli bireylerde problem çözmeye ilişkin araştırmalarda genel olarak tek bir stratejiye (şemaya dayalı problem çözme, kendini izleme stratejisi, anla ve çöz! stratejisi, somut-yarı somut-soyut öğretim stratejisi, onluk kart, abaküs ve parmak sayma stratejisi, Touchmath) odaklanıldığı görülmektedir (Can-Çalık, 2008; Casner, 2016; Cihak, 2010; Karabulut, 2015; Kot, 2014; Nar, 2018; Rumiati, 2017; Tufan, 2016; Tuncer, 2009). Bu çalışmada ise zihinsel engelli öğrencilerin öğrenebileceği, uygulayabileceği ve seviyelerine uygun olduğu düşünülen üç problem çözme stratejine (tahmin ve kontrol; şekil, şema ve diyagram çizme; geriye doğru çalışma) odaklanılmışır.

\subsection{Kavramsal Çatı}

Zihin engelli bireyler; günlük yaşam sürecini öğrenme ve bu süreci yerine getirmede ciddi güçlükler yaşayan, zekâ testlerinde alınan puanın iki standart sapmanın altında olan, zihinsel işlevlerin yanı sıra, uyumsal becerilerde de sinırlılıkları olan bireylerdir. Uyumsal becerilerdeki sınırlılıklar zihinsel işlevlerdeki sınırlılıklarla ilişkilidir (Amerikan Zeka Geriliği Birliği [American Association on Mental Retardation-AAMR], 2002). "Sınılılıktan söz edebilmek için on beceri alanından (iletişim, öz bakım, ev yaşamı, sosyal beceriler, toplumsal yararlılık, kendini yönetme, sağlık ve güvenlik, işlevsel akademik beceriler, boş zaman ve iş) en az ikisinde sınırlılı̆ı̆ bulunması gerekmektedir. Bu beceri alanları başarılı bir yaşam sürdürmenin temelinde yer almaktadır. Zihin engellilerin özel eğitim gereksinimlerinin önemli bir bölümü bu becerilerle yakından ilişkilidir. Her bir beceri alanında yer alan beceriler takvim yaşına göre farklılık gösterebilmektedir" (Eripek, 1998, s. 3940). Zihinsel engellilerin büyük bir bölümünü akranlarından hafif derecede gerilik gösteren çocuk ve gençler oluşturmaktadır. Amerika Psikiyatri Birliğince yayınlanan DSM-V Tanı Ölçütleri El Kitabı'nda zihinsel gerilik, anlıksal yetiyitimi olarak tanımlanmış ve dört gurupta sınıflandııılmıştır. Ancak bu sınıflandırma IQ puanlarına göre değil, uyarlanabilir, uyumsak davranışlara dayanarak tanımlanmıştır. Anlıksal yetiyitiminin ağırlık düzeyleri ăgır olmayan, orta derece, ăgır, çok ăgır olarak sınıflandırılmıştır. Ağırlık düzeylerinin tespitinde, kavramsal etki alanı, sosyal etki alanı ve pratik etki alanı başlıkları altında yaşamsal becerileri uygulayabilme seviyeleri göz önünde bulundurulur (American Psychiatric Association [APA], 2013).

Hafif düzeyde zihinsel yetersizliği olan birey; "Zihinsel işleveler ile kavramsal, sosyal ve pratik uyum becerilerinde hafif düzeydeki yetersizliği nedeniyle özel eğitim ile genel eğitim hizmetlerine slnırl düzeyde ihtiyaç duyan bireydir" (Metin ve Işıtan, 2017, s. 161). "Bu guruba giren çocuklar genellikle, normal eğitim veren okulların bünyesinde özel alt sınıflarda eğitim görmektedirler. Bu öğrencilerin sınıf öğretmenlerine danışmanlık hizmeti verilerek veya öğrenciye destek hizmet verilerek normal sınıflarda eğitim alması sağlanmaktadır. Hafif düzey zihinsel yetersizliği olan çocuklar okula başlayana dek, hatta daha ileri sınıflara gelene kadar fark edilemeyebilirler. Ancak ileri sınıflarda farkına varılır. Çünkü okulda ve ileri sınıflarda onlardan beklenilen görevler giderek zorlaşmaktadır" (Eripek ve Vuran, 2016, s. 252). Bu durum öğrencilerin geç fark edilmelerine ve özel eğitim hizmetinden mahrum kalmalarına neden olmaktadır. Hafif düzey zihinsel engelli çocukların ilkokul ve ortaokul özel alt sınıflarına devam etmeleri yaygın bir durumdur. Fakat ortaöğretim dönemine geldiklerinde, çok fazla özel alt sınıfı olan ortaöğretim kurumu bulunmamaktadır. Bu yüzden bu öğrencilerin lise dönemlerini daha verimli geçirebilmeleri için eğitimlerine Milli Eğitim Bakanlığ 1 bünyesinde hafif düzeyde zihinsel engelliler için özel eğitim liselerinde devam etmektedirler.

Hafif düzeyde zihinsel engelli çocuklar için hazırlanmış programlar mevcuttur. Bunun yanı sıra hafif derecede engelli birçok çocuk genel eğitim programlarından da yararlanabilmektedir. Genel eğitim programlarında destek hizmeti sağlandığ 1 takdirde, bu çocuklarda özel eğitim programlarına gereksinim duyulmamaktadır. "Bu çocuklar için, üç gurup model vardır. Bunlar, yaşam merkezli model, süreç öğretimi modeli ve akademik modeldir. Yaşam merkezli model; zihinsel engelli bireylerin yaşam becerilerini geliştirmeyi hedefleyen modeldir. Süreç öğretimi modeli; zihinsel işlevlerin düzeltilmeye çalışıldığı modeldir. Akademik model; hafif düzeyde engelli öğrencilerin en fazla karşı karşıya kaldıkları modeldir. Okuma ve matematik gibi akademik becerilerin gelişmesinin hedeflendiği modeldir" (Sucuoğlu, 2016, s. 236). Milli Eğitim Bakanlığı'nın hafif dizeyde zihinsel engelli öğrencilerin ortaöğretim matematik öğretim programında genel olarak; öğrencilerin yaşamlarındaki problemleri çözebilme becerisine erişmeleri için yeni fikirler üretebilme yetisi kazanmaları amaçlanmalıdır. Bu yetiye ulaşmaları için öğrencilerin eğitim ortamının yaşamları ile uyum içerisinde olması önemlidir. Eğitim ortam ve programları hazırlanırken öğrencilerin yaşam koşullarına ve seviyelerine uygun olması esastır. Zihinsel öğrenme yetersizliği olan öğrencilerde, soyut kavramların öğretiminde zorluklar yaşanmaktadır. $\mathrm{Bu}$ nedenle bu öğrencilere matematiğin temel kavramlarının ve ilkelerinin öğretiminde daha 
somut örneklerle çalışılmalı ve yakın çevrelerinden örnekler seçilmelidir. Öğrencilerin performanslarına göre somuttan soyuta ve yakından uzağa doğru örneklerle öğrencilerin soyut düşünmelerine ulaşacak imkânlar sunulmalıdır. Matematikte problem çözme becerilerine ulaşabilmeleri için sayı, işlem, sayılar arasındaki ilişkiyi anlayabilme ve problem çözme aşamalarının becerilerine erişmiş olmaları gerekmektedir (MEB, 2018) ifadeleri yer almaktadir.

"Problem, zihni karıştıran ve inancı belirsiz hale getiren durumlar olarak ele alındığında problemin çözümü, belirsiz durumları ortadan kaldırmak olacaktır" (Baykul, 2014, s. 68). Problemi çözmek; yüzmek, kayak yapmak veya piyano çalmak gibi pratik bir sanattır. Sadece taklit ve pratik yaparak öğrenebilirsiniz. Yüzmeyi öğrenmek istiyorsanız suya girmeniz gerekir ve bir problem çözücü olmak için sorunları çözmeniz gerekir (Polya, 1962, s. 9). "Problem çözme, problem durumu karşısında ne yapılacağını bilmedir. Problem çözme süreci, belirli bir amaca ulaşmak için, atılacak adımların, yapılacak etkinliklerin açık bir şekilde belli olduğu, amaca ulaşmak için kontrollü bir şekilde araştırmanın yapıldığı süreç olarak açıklanır" (Altun, 2008, s. 58). "Problem çözme yeteneği, bir problemle karşı karşıya kalındığında, onun içeriğini kavrayıp problemi anlama, çözümü için uygun çözüm yolunu seçme, bu çözüm yolunu kullanabilme ve çözüm sonuçlarını yorumlama yeteneklerini geliştirmektir" (Baykul ve ark., 2010, s. 13).

"Bütün problemlerin çc̈züm sürecinde kullanılan sabit bir yol ya da yöntem bulunmamaktadır. Eğer böyle bir yöntem olsaydı sorun kökünden halledilmiş olurdu" (Altun, 2008, s. 60). Problem çözme faaliyetlerinin uygulanması sırasında tutarlı bir biçimde görülen bir diğer önemli husus, öğrencilerin problemin çözümlerine ve çözümlerine ulaşma sürecine dikkat etmeleridir. Bu, bir problem üzerinde çalı̧ırken öğrenciler için asıl amacın çözümü bulmak olduğu fikrine meydan okumaktadır. Sürece dikkat etmek öğrencilere çeşitli çözüm yöntemlerinin niteliklerini analiz etme, karşılaştırma, problemin uygulamalarını ve uzantılarını arama firsatı verir. Bir problemin çözümü, yeni matematiksel düşünceleri başlatmak için başlangıç noktasıdır. Bu nedenle, öğrenciler farklı problemler üzerinde çalışmaya ve orijinal problemin bağlantılarını ve uzantılarını aramaya teşvik edilir (Santos-Trigo, 1998, s. 639). Problem sürecini anlamak, nasıl çözüldüğünü keşfetmek ve nihayetinde sonuca ulaşmak öğrencinin problem çözmeyi öğrenmesi için çok önemlidir. Öğrenciye sadece sonucu bulma odaklı eğitim verilirse, öğrenci problemin nasıl çözüleceğini hiçbir zaman merak etmeyecek ve ezberlenmiş çözümlerden öteye bir öğretim gerçekleşmeyecektir. Öğrencinin bilgiyi yapılandırması, problem çözümlerinde aldığı eğitimleri başka problemlerin çözümlerine yansıtması için öğrencinin problem çözme sürecini iyi bir şekilde özümsemesi ve benimsemesi gerekmektedir. O yüzden problem çözme sürecinde izleyeceğimiz yol veya yollar bilimsel açıdan da pedagojik açıdan da tutarlı ve birbirini destekler nitelikte olmalıdır.

Polya'nın problem çözme süreci bilimsel anlamda da eğitim anlamında da matematik dünyasında kendisini kanıtlamış bir yöntemdir. Problem çözücünün ilk olarak problemi anlaması, problemde ne istendiğini açıkça görmesi gerekir. Problemi anlaması için problemin verilenlerini ve istenenlerini analiz etmesi ve bu ikisi arasındaki bağı bulması gerekir. İkinci aşamada, çeşitli kavramların birbirleriyle nasıl bir bağlantı içinde olduğunu, çözüm hakkında bir fikir oluşturmak ve nihayetinde bir çözüm planı oluşturmak için bilinmeyenin verilenlerle nasıl bağlantı içerisinde olduğunu görmesi gerekir. Problemin verilerine ve istenenlerine göre bir plan yapmalıdır. Üçüncü olarak, planı uygulaması ve dördüncü aşama olarak, tamamlanan çözüme geri dönerek çözümü gözden geçirip kontrol etmesi gerekir (Polya, 2017, s. 5).

Matematikte problem çözme stratejisi, bir problemin çözümünde izlenecek yolu belirlemek için, hangi adımların atılacağını, problemin nasıl çözüleceğini belirlemek adına seçilen yöntemdir. Problem çözücü problemi hangi stratejiyi kullanarak çözmeyi düşünüyorsa, seçtiği strateji kendisinin yöntemi olacaktır. Polya'nın problem çözme sürecinde, plan yapma aşamasında strateji seçimi vardır. Bu stratejilerden bazıları; (1) bilinçli tahmin ve kontrol, (2) daha basit denk bir problem çözme, (3) canlandırma ve benzetim, (4) geriye doğru çalışma, (5) örüntü bulma, (6) mantıksal akıl yürütme, (7) çizim yapma, (8) farklı bir bakış açısı benimseme (Posamentier ve Krulik, 1998) şeklinde sıralanabilir. Baykul ve arkadaşları (2010), bu stratejilerin yanında (9) model inceleme, (10) tablo yapma, (11) sistematik liste yapma, (12) matematik cümlesi yazma, (13) denemeyanılma, (14) eleme, (15) bilinenleri eleştirel biçimde inceleme stratejilerini de sıralamaktadır.

Çalışmada hafif düzeyde zihinsel engelli öğrencilere öğretimi yapılan problem çözme stratejilerinden tahmin ve kontrol stratejisinde bir tahmin yapılır, bu tahmin mantıklı bir tahminse çözüme ulaştırır. Eğer tahmin başarısız bir tahmin dahi olsa çözüme yaklaşmada yardımcı olacaktır. Çünkü başarısız tahminden sonra çözüme ulaşmak için yeni bir fikir sunar, problemin daha iyi anlaşılmasına yardımcı olur ve çözüme yaklaştırır. Her bir tahminin sonunda problemin çözümüne daha çok yaklaşılır ve sonuca ulaşılır (Baykul, 2014, s. 72). Şekil, şema ve diyagram çizme stratejisinde oluşturulan şekil ve şema problemin anlaşılmasını kolaylaştırır, problemin bir bütün olarak görülmesini sağladığı gibi çözüm için bir yol bulmada yardımcı olur. Şekil, problemde verilenler ile istenenler arasında görsel bir bağ kurarak problemin çözümünün görsel ögelerle gerçekleştirilmesidir. (Baykul, 2014, s. 73). Bazı problemlerde başlangıç kısmı yerine problemin sonucu verilir ve böyle problemlerde başlangıç kısmının bulunması istenir. Bu tür problemlerin çözümünde geriye doğru çalışma stratejisine başvurarak 
problemin sonucundan başına doğru gidilebilir. "Bu süreçte hem eylemleri hem de işlemleri tersine çevirerek adım adım ilk bilgilere ulaşılmaya ve problemi bu yolla çözmeye çalışılır” (Altun, 2008, s. 86).

\section{Yöntem}

Araştırmada, zihinsel yetersizliği olan öğrencilere problem çözme becerisinin kazandırılmasında problem çözme stratejileri ile yapılan öğretimin etkililiğini incelemek üzere nitel araştırma modellerinden öğretim deneyi (teaching experiment) modeli kullanılmıştır. Öğretim deneyi deseni araştırmacıların, kendi etkinliklerini düzenlemelerinde kullandıkları kavramsal bir araç olarak tanımlanabilir. Piaget'nin klinik görüşme tekniğinden üretilmiş olmasına karşın, öğrencilerin matematiksel bilgilerinin ortaya çıkarılmasının yanı sıra bu bilgilerin etkilenme yollarının/araçlarının ve durumlarının deneyimlenmesini de kapsadığından klinik görüşmeden daha kapsamlıdır (Steffe ve Thompson, 2000) Klinik görüşme, öğrencinin mevcut bilgilerini anlamaya yönelikken öğretim deneyi ise, öğrencilerin uzun bir süre sonunda elde ettiği ilerlemeleri anlamaya yöneliktir. Öğretim deneyi dört bölümden oluşur, birincisi ögretim aşaması, ikincisi araştırmact veya öğretmen, üçüncüsü bir veya birden fazla öğrenci, dördüncüsü ise ögrretim sürecinin gözlemi ve bu süreçte yaşanılan bütün aşamaların video kaydl altına alındığı bir yöntemdir (Steffe ve Thompson, 2000). Öğretim deneyi modelinin uygulama aşamasındaki ders planlarının hazırlanması ve öğretim sürecinde, özel eğitimde kullanılan doğrudan öğretim yöntemi tercih edilmiştir.

Doğrudan öğretim, Engelmann'ın (1998) 1960'larda kendi çocuklarına öğretim yaparken geliştirdiği ve binlerce öğrenci üzerinde çalı̧̧arak, test edip düzenlediği bir yöntemdir. Doğrudan öğretim üç önemli durumu kapsamaktadır. Bunlar ögrretimin planlanması, öğretimin sunumu sürecinde uygulanan teknikler ve öğretimin düzenlenmesidir. Hemen hemen bütün öğrencilerin matematiği öğrenebileceği tutumu, doğrudan öğretimin doğasındadır (Polloway, Serna, Patton ve Bailey, 2014, s. 211). "Doğrudan öğretim yöntemi; model olma, rehberli uygulama ve bağımsız uygulamalar olmak üzere üç aşamadan oluşmaktadır. Öğretim uygulamaları öğretmen tarafindan yönlendirilerek yapılır” (Bağlama, 2018, s. 30).

Doğrudan öğretimin ilk aşaması olan model olmada, öğretmen aktif bir şekilde öğrenciye model olmaktadır. $\mathrm{Bu}$ aşamada öğretmen, doğrudan konunun öğretimini üstlenirken, öğrenci gözlemleyen ve dinleyen konumdadır. Öğretmenin rehber görevi gördüğü ikinci aşama, rehberli uygulama; öğrencinin aktif olarak sürece bizzat katıldığı aşamadır. Öğrenci artık yavaş yavaş öğretimin içerisinde yer alır ve ilerlemeye başlar. Bu süreç doğrudan öğretim içinde önemli bir süreçtir. Üçüncü aşama olan bağımsız uygulamada, öğrenciden öğretimi yapılan konunun çözümleri için kendi kararlarını verip uygulaması beklenir. Bu uygulamanın her seferinde ustalıkla olması gerekir. Öğrencinin bu duruma gelebilmesi için model olma basamağı ve rehberli uygulama basamağının, öğretmen tarafından çok titiz bir şekilde ipuçlarıyla, teknoloji desteğiyle ve zengin eğitim materyalleri ile öğrenciye sunulmuş olması önem arz etmektedir (Engelmann ve Carnine, 1991)

\subsection{Katılımcilar}

Katılımcıların belirlenmesinde amaçlı örnekleme yöntemlerinden, ölçüt örnekleme kullanılmıştır. Bu amaçla Milli Eğitim Bakanlı̆̆’'na bağlı Özel Eğitim Mesleki Eğitim Merkezi Okulu'nda öğrenim gören hafif düzeyde zihinsel engele sahip 9 olası katılımcıya, araştırmacı tarafindan geliştirilen okuduğunu anlama testi, matematiksel dört işlem testi ve problem çözme testi uygulanmıştır. Söz konusu araçlar Türkçe alan uzmanının, özel eğitim alan uzmanının ve matematik alan uzmanının görüşleri doğrultusunda geliştirilerek kullanılmıştır. Öğrencilerin bahsi geçen ölçme araçlarına verdikleri cevaplar ve öğretmen görüşleri değerlendirilerek, problem çözme stratejilerine ilişkin öğretimin yapıldığ 1 öğrenci grubu belirlenmiştir. Öğrenci seçiminde kullanılan ölçüt; okuduğunu anlama testinden en az \%75 başarı elde etme; eldeli toplama ve onluk bozmayı gerektiren çıkarma işlemleri ile çarpma ve bölme işlemleri içeren dört işlem testinden en az \%50 başarı elde etme ve problem çözme testinde yer alan en az bir işlem içeren 5 problemden en az ikisini çözebilme olarak belirlenmiş̧ir. Araştırmanın katılımcı grubu, 2018-2019 öğretim yılında Ege Bölgesinde bulunan bir il merkezinde bulunan hafif düzeyde zihinsel engelli öğrencilere eğitim veren bir özel eğitim mesleki eğitim merkezi okulunun, gönüllü ve çalışma şartlarına uygun, 9 öğrencisi arasından ölçütleri karşılayan 3 öğrencisi seçilerek oluşturulmuştur. Yaş aralı̆̆ 1518 yaş olan özel eğitimin lise grubu öğrencilerinden cinsiyet farkı gözetmeksizin koşullara uygun üç öğrencinin ikisi erkek biri kız öğrencidir. Öğrencilerin ölçütleri karşılama durumu değerlendirildiğinde; seçilen üç öğrencinin, genel olarak problem çözebildikleri, öğretimi yapılmadığı halde faklı stratejiler kullanabildikleri, okuduğu problemleri anlamada diğer öğrencilere göre daha ileride oldukları ve çalışmaya katılmak için istekli oldukları belirtilebilir. Katılımcı üç öğrencinin hastane sağlık kurulu raporları ve rehberlik araştırma merkezinden alınan bilgilere göre; T öğrencisinin Stanford-Binet Zeka test puanı IQ 63, F-70 hafif düzeyde mental retardasyon tanısı, yetersizlik durumuna göre tüm vücut fonksiyon kaybı \%50'dir. M öğrencisinin Stanford-Binet Zeka test puanı IQ 61, F-78 hafif düzeyde mental retardasyon tanısı, yetersizlik durumuna göre tüm vücut fonksiyon kaybı \%50'dir. K öğrencisi WISC-R SIQ58-PIQ70-TIQ62 test puanı, hafif düzeyde mental retardasyon+epilepsi klinik tanısı, yetersizlik durumuna göre tüm vücut fonksiyon kaybı \%53'dür 


\subsection{Veri Toplama Aracı / Araçları}

Araştırmanın verisini araştırmacı tarafindan doğrudan öğretim modeline göre hazırlanmış olan ders planlarının bağımsız uygulama aşama 1 ve aşama 2'deki problemlere öğrencilerin vermiş̧ oldukları cevaplar ile bu aşamadaki video kaydına yansıyan görüntülerin transkripsiyonları oluşturmaktadır. Öğrenciler için hazırlanıp verilen takip formaları, video transkripsiyonları ile birleștirilerek bir bütün halinde verilere kaynak olmuştur. Her bir problemin çözümünde öğrenci takip formunu kullanarak eğitim almış ve uygulamasını yapmıştır. Takip formunun kullanılması, öğrencinin süreci tam olarak özümsemesi için seçilmiş bir durumdur.

\subsection{Verilerin Analizi}

Verilerin analizinde betimsel analiz kullanılmıştır. "Betimsel analizle, öğretim yapılan bireyleri tanıtıcı bulgular değerlendirilir, içerik analizi yoluyla veriler tanımlanmaya çalışılır, birbirine benzediği ve birbiri ile ilişkisi olduğu tespit edilen veriler belirli kavramlar, temalar ve kodlar çerçevesinde bir araya getirilerek yorumlanır" (Karataş, 2017, s. 79). "Betimsel analiz dört aşamadan oluşur (Yıldırım ve Şimşek, 2008, s. 224): (1) Betimsel analiz için bir çerçeve oluşturma, (2) Tematik çerçeveye göre verilerin işlenmesi, (3) Bulguların tanımlanması ve (4) Bulguların yorumlanması". Bu çalışmada temaların oluşturulmasında Polya'nın (2017) problem çözme aşamaları; problemi anlama, plan yapma ve planı uygulama aşamaları ana temalar olarak belirlenmiştir. Bu temalar altında kodlamalar yapılarak bu kodlamalara uygun şekilde bulgular oluşturulmuştur.

Kodlama güvenirliğinin sağlanması amacıyla araştırmacının dışında bir özel eğitim alan uzmanı kodlayıcı olarak belirlenmiştir. Kodlamalar sadece bağımsız uygulama aşamaları (Aşama 1 ve Aşama 2) için yapılmıştır. Kodlayıcılar araştırma verisini birbirlerinden bağımsız biçimde kodlamışlardır. Ortaya çıkan tüm kodlar "benzeşen kodlar" ve "ayrışan kodlar" ş̧eklinde sınıflanmıştır. Miles ve Huberman (1994) benzeşen kodları "Görüş Birliği" ayrışan kodları ise "Görüş Ayrılı̆̆ı" olarak adlandırmakta ve kodlayıcı güvenirliği için Uyuşma Yüzdesi = Görüş Birliği / (Görüş Birliği + Görüş Ayrıllı̆ı) formülünü önermektedir. Araştırma kapsamında yukarıdaki formüle göre hesaplanan Miles-Huberman Uyum Yüzdesi 0.80 olarak elde edilmiştir. Bu da kodlama güvenirliği yönünden yeterli düzeyde şeklinde alınmıştır.

Özel eğitim alan uzmanının görüşleri doğrultusunda ders planlarının bağımsız uygulama aşama 2'ye kadar tüm aşamalarında kontrol formu kullanılmıştır. Bu form ile hem öğrencilerin öğrenme süreçleri kontrol altında tutulmuş hem de verinin analizi aşamasında kodların belirlenmesi kolaylaşmıştır. Kontrol formunun kullanımının kodlama güvenirliğini artırdığı ifade edilebilir. Verilerin oluşturulmasında temel veri toplama yöntemlerinden, katılımcı gözlem, belge incelemesi ve araştırmanın öğretim sürecinde öğrenci ile yapılan görüşmenin video kaydı alınarak transkripsiyonu kullanılmıştır. Böylelikle katılımcıların öğretimi nasıl algıladığı, kavramsallaştırdığı ve değerlendirdiği ortaya çıkarılmaya çalışılmıştır. Mevcut veri toplama yöntemleri yanında destekleyici veri toplama yöntemlerinden video kayıı yöntemi ile veriler çeşitlendirilerek araştırmanın geçerliliği ve güvenirliği arttırılmaya çalışılmıştır.

\subsection{Süreç}

Öğretimde üç stratejinin (tahmin ve kontrol; şekil, şema ve diyagram çizme; geriye doğru çalışma) öğretimi yapılmasına karar verilmiştir. Bu üç stratejinin seçiminde, stratejilerin çok fazla akıl yürütmeyi, denklem yazmayı ve karmaşık işlemleri gerektirmemesi tercih nedeni olmuştur. Stratejiler belirlendikten sonra, her bir strateji için doğrudan öğretim modeline uygun (öğrenciyi güdüleme, model olma, rehberli uygulama ve bağımsız uygulama) ders planları hazırlanmıştır. Doğrudan öğretim yöntemine göre hazırlanan ders planlarında yer alan problemlerin 18 tanesi araştırmacılar tarafından özgün olarak hazırlanırken, 6 tanesinin oluşturulmasında Posamentier ve Krulik (1998) de yer alan problemlerden esinlenilmiştir. Bütün problemler, matematik eğitimi ve özel eğitim alan uzmanlarının görüşlerine sunulmuş, gerekli düzeltmeler yapılarak uygulanmıştır. İlk ders planları kapsamlı bir şekilde birer adet olarak hazırlanıp matematik eğitimi ve özel eğitim alanında uzmanların görüşüne sunulmuştur. Matematik eğitimi alan uzmanının görüşleri doğrultusunda problemlerin içeriği ve öğretimi düzeltilmiştir. Özel eğitim alan uzmanının görüşleri doğrultusunda, öğrencilerin özel eğitim öğrencisi olması nedeniyle, öğretim sürecinde model uygulama, rehberli uygulama ve bağımsız uygulama basamağında kullanılmak üzere öğrencilere Takip Formu geliştirilmiştir. Her bir problemin çözümünde öğrenci takip formunu kullanarak eğitim almış ve uygulamasını yapmıştır. Takip formunun öğretim sürecine dâhil edilmesiyle doğrudan öğretimin bağımsız uygulama basamă̆ iki aşamaya çıkarılarak Aşama 1 ve Aşama 2 şeklinde iki değerlendirme yapılmıştır. Aşama 1'de öğrencinin takip formunu kullanmasına izin verilirken, Aşama 2'deki değerlendirmede öğrenciye takip formu verilmeden boş bir A4 kâğıdı üzerinde tamamen bağımsız uygulama yapması istenmiştir. Her bir strateji ders planında 4'er adet olmak üzere 8 problem öğretimi ve çözümü yapılmıştr. Toplamda üç stratejiden 24 adet problem üzerinde çalışmıştır. Katılımcı gurupla öğretim yapmadan önce katılımcı olmayan başka bir öğrenci ile her bir plan için pilot uygulama yapılarak tekrar değerlendirmeler yapılıp asıl katılımcı grup için hazırlıklar yapılmışır. Her bir stratejinin bir ders planı $5 * 40$ dakika şeklinde planlanmış ve öğretim öğrencilere bir sınıf ortamında birebir öğretim şeklinde yapılmıştır. Her bir ders planının uygulaması bir buçuk hafta sürmüştür. Öğretim sürecinin tamamı video kamera ile kayıt altına alınmıştır. Her bir 
basamaktan sonra öğrencinin kontrol formu ve A4 cevap kâğıdı kayıt altına alınmıştır. Sınıfın içerisinde farklı öğretimlerde kullanılan materyaller duvarlarda asılı olarak bulunmaktadır. Öğrencilere öğretim yapılırken gerekli materyaller araştırmacı tarafindan sunulmuştur. Öğretimler beyaz tahtada, problemler projeksiyon yardımı ile yansıtılarak sunulmuştur. Öğrencilerin oturabilmesi için masa ve sıralar ile öğretmen masası vardır. Öğretimler esnasında öğrenci sınıfta bulunan öğretmen masasına ve koltuğuna beyaz tahtanın karşısına gelecek şekilde yerleştirilmiştir. Kamera model uygulama basamağında araştırmacının öğretimi yaptı̆̆ı sırada tahtayı görecek şekilde konumlandırılmıştır. Rehberli uygulamada araştırmacı bir sandalyeyi öğrenci masasının yanına yerleştirerek öğrenci ile yan yana oturmuştur. Bu sırada kamera hem öğrenciyi hem de araştırmacı ve çalışma kâğıdını görecek şekilde konumlandırılmıştır. Bağımsız uygulama basamağında ise araştırmacı ayakta, kamera ise öğrenci ve kâğıdını görecek şekilde masanın yan tarafında konumlandırılmıştır.

\section{Bulgular}

Araştırmanın bulguları üç problem çözme stratejisine ilişkin ana başlıklar halinde verilmiştir. Bu stratejilerin birincisi Tahmin ve kontrol stratejisi, ikincisi şekil, şema ve diyagram çizme stratejisi, üçüncüsü ise geriye doğru çalışma stratejisidir. Her bir öğrencinin gösterdiği performanslar ana temalar ve kodlamalara göre değerlendirilerek bulgular açıklanmıştır. Üç ayrı strateji kendi içinde değerlendirilmiş olup öğrencilerin bulguları stratejiler başlığı altında sunulmuştur.

Tahmin ve kontrol stratejisine ilişkin bulgular genel olarak değerlendirildiğinde; öğrencilerin problemi okuduktan sonra verilenler ve isteneler basamaklarını oluşturmaya çalıştıkları ve bu aşamada $T$ öğrencisi haricinde diğer öğrencilerin bu basamakları doğru bir şekilde oluşturduğu gözlenmiştir. $T$ öğrencisinin problemin ç̧̈zümü için verilenlere bakmadan direkt problemle muhatap olduğu gözlenmiştir. Öğrenci T'nin verilenler basamağını, "problemde bize hangi kavramların bilgisi verilmiştir" olarak anladığı görülmektedir. Bu kavramların değerlerini yazma gereği duymamaktadır. İstenenleri oluştururken aslında bulmasına gerek olmayan, verilenlerde belirtilmiş olan değerleri de bulması gerekiyormuş gibi hepsiyle birlikte olarak istenenleri oluşturduğu gözlenmiş̧ir. Problemin çözümü için tahmin ve kontrol stratejisini seçtiğini gösterir şekilde "tahminlerim için tablo çizeceğim" ifadesini kullanmıştır. Tablosunu ve başlıklarını doğru şekilde oluşturduğu gözlenmiştir fakat problemin çözümünü tablo üzerinde yapmak yerine ayrı bir A4 kâğıdı üzerinde çözmeye başladığı görülmüştür. Problemin çözümü için tahmin ve kontrol stratejisini kullanmak yerine, daha önce öğretimi yapılmayan, tamamen kendi kendine yapabildiği, uç değerleri kullanarak ve akıl yürüterek çözüme ulaşmaya çalıştığ 1 görülmüştür. Öğrencinin öğretimi yapılan tahmin ve kontrol stratejine uygun adımlarla çözüme başladığı ancak çözüm sürecine geçtiğinde farklı bir stratejiyle problemi çözmeyi tercih ettiği gözlenmiştir. Uç değerleri kullanma ve akıl yürütme stratejini uygulamada sorun yaşamadan problemi çözebildiği, problemin sonucuna ulaştığını düşündükten sonra, bulduğu sonuçları tablo üzerinde de tahmin kısmına yazarak, tahminini zihinden matematiksel işlem yaparak çözdüğü görülmüştür. Öğrencinin problemi tahmin ve kontrol stratejisi ile de çözdüğü gözlenmiştir.

Öğrencilerin Polya'nın problem çözme aşamalarından problemi anlama basamağında genel olarak başarılı oldukları gözlenmiştir. Öğrencilerin bütün problemlerde tahmin ve kontrol stratejisini seçerek, stratejinin tahminleri için tablo çizebildiği gözlenmiştir. M öğrencisinin ilk uygulamalarda tablonun başlığını oluşturmada problemler yaşadığını ama diğer öğrencilerin tablo başlıklarını genel olarak oluşturabildiği gözlenmiş̧tir. Son uygulamalarda $\mathrm{M}$ öğrencisinin de tablonun başlıklarını oluşturabildiği gözlenmiştir. Bu durum öğrencilerin tahmin ve kontrol stratejisini kullanmada tablodan etkin biçimde yararlanabildiklerini gösterir. Öğretimi ve değerlendirmesi yapılan problemlerde genel olarak stratejiye uygun tahminleri yapabildikleri gözlenmiştir. Tahminlerinin sonuçlarını verilenlerle kıyaslayarak tahmin sonuçlarını kontrol ettikleri gözlenmiştir. Problemin içerisinde ilave kriter olan problemde, bütün öğrencilerin kritere takılı kaldıkları, stratejiyi uygulayamadıkları gözlenmiştir. Tahminleri arasındaki sistematik bağı göremeyen öğrencilerin tahmin sayısının arttığı ve kafalarının iyice karıştığı, bu yüzden de stratejiyi doğasına uygun kullanamadıkları gözlenmiştir. Dolayısıyla araştırmanın tahmin ve kontrol stratejisine ilişkin bulguları çerçevesinde, öğrencilerin karmaşık kriterler barındırmayan problemlerde söz konusu stratejiyi işe koşabildikleri, değişkenler arasındaki ilişkiyi belirleyen bir kriterin bulunması durumunda ise zorlandıkları tespit edilmiştir. Çözüm sürecine ilişkin öğrenci cevaplarından örnek görüntüler Şekil 1'de sunulmuştur. 


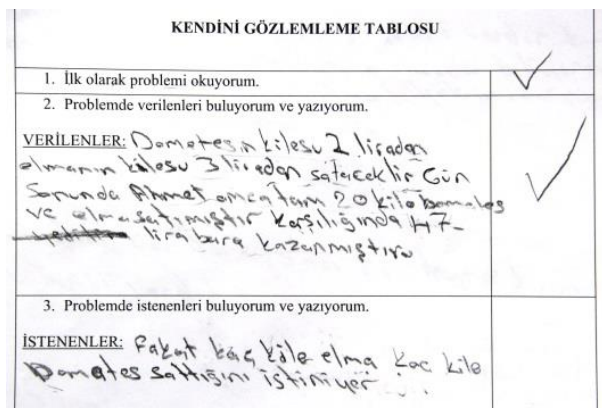

a) $T$ öğrencisi verilenler-istenenler

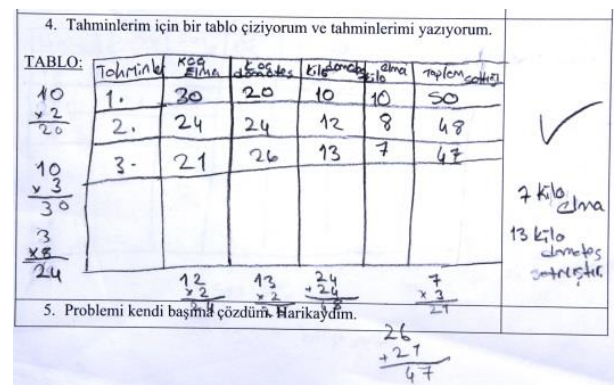

b) M Öğrencisi tablo başlıkları oluşturma

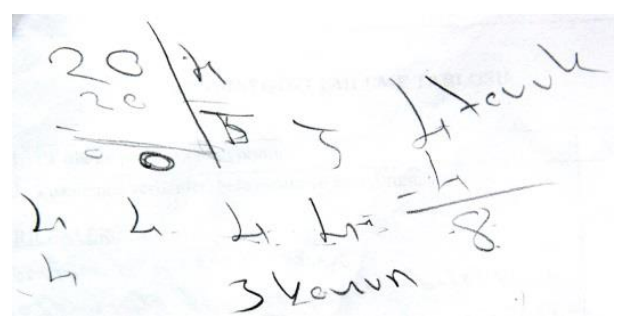

c) T öğrencisi uç değerleri kullanma stratejisi

Şekil 1. Tahmin ve kontrol stratejisine ilişkin öğrenci cevaplarından örnek görüntüler

Şekil, şema ve diyagram çizme stratejisine ilişkin öğretim sonrasında bağımsız uygulama bulguları değerlendirildiğinde; bütün öğrencilerin problemin verilenlerini ve istenenlerini oluşturma noktasında $T$ öğrencisi haricinde genel olarak başarılı oldukları görülmüştür. T öğrencisinin de verilenleri oluştururken problemi çok dikkatli okumaması sebebiyle genelde eksik bilgiler yazdığı görülmüştür. Problemin çözümü için bütün öğrencilerin şekil, şema ve diyagram çizme stratejisini seçebildiği ve uygulamaya geçebildiği gözlenmiştir. Uygulama aşamasında problemin verilenlerine uygun şekiller çizebildikleri görülmüştür. Problemlerde birden fazla kriter ve yönerge olması durumunda öğrencilerin farklı oranlarda bu kriterlere ve yönergelere takılı kaldığı görülmüştür. Bu takılmalardan dolayı stratejiyi uygulayamadıkları ya da zorlandıkları gözlenmiştir. Araştırmacının yönlendirmesi ile kriterleri gerçekleştirebildikleri görülmüştür. Bir öğrencinin çok zorlandığ1, hatta uygulamakta başarılı olamadığ 1 kriteri bir diğer öğrencinin hiç zorluk çekmeden başarılı bir şekilde uygulayabildiği görülmüştür. Problemlerin çözüm sonucuna öğrencilerin genel olarak ritmik sayma ile işlem yaparak, zihinden matematiksel işlem yaparak veya şekil üzerinden işlem yapmadan direkt ulaşabildikleri gözlenmiştir. Öğrencilerin bireysel farklılıklarının stratejiyi uygulama noktasında ciddi farklılıklara neden olduğu görülmüş̧ür. Ancak genel olarak öğrencilerin stratejinin doğasını anladığı ve uygulamaya koyabildiği tespit edilmiştir. Çeşitli nedenlerle stratejiyi uygulamakta zorlandıkları noktalarda araştırmacının yönlendirmesi ile başarılı oldukları gözlenmiştir. Çözüm sürecine ilişkin öğrenci cevaplarından örnek görüntüler Şekil 2'de sunulmuştur.

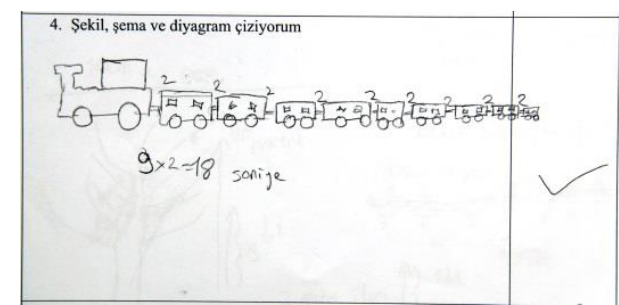

a) M öğrencisi bağlama uygun şekil yapma

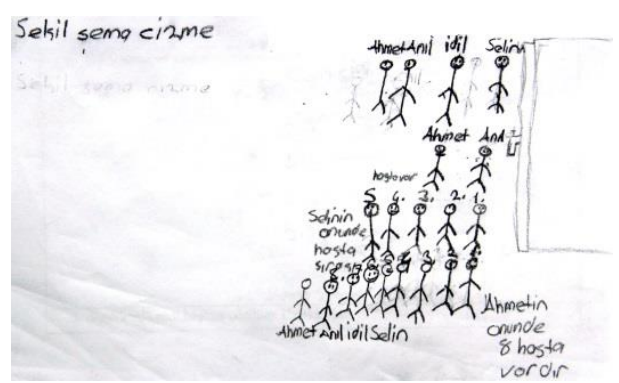

b) K öğrencisi kritere takılı kalma

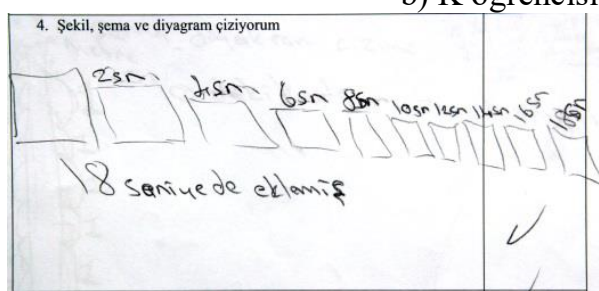

c) $\mathrm{T}$ öğrencisi verilenlere uygun şekil yapma

Şekil 2. Şekil, şema ve diyagram çizme stratejisine ilişkin örnek öğrenci cevapları 
Geriye doğru çalışma stratejisine ilişkin bulgular genel olarak değerlendirildiğinde; öğrencilerin tümünün verilenleri ve istenenleri oluşturmada başarılı olduğu gözlenmiştir. Problemin çözümü için bütün öğrencilerin öğretimi yapılan stratejiyi seçip uygulamaya çalıştıkları görülmüştür. Problemlerin çözümünde geriye doğru çalışma stratejisinin yanında daha önce öğrendikleri şekil, şema ve diyagram çizme stratejisini de kullanabildikleri görülmüştür. Problemde en son verilenden ilk verilene doğru geriye doğru hareket etmek ilk başlarda öğrenciler için zor görünse de, üzerinde çalışılan problem sayısı artıkça geriye doğru gitmekte zorlanmadıkları görülmüştür. Çözdükleri problemin türü değişince geriye doğru gitmekte zorlandıkları, çokça örnek olarak yaptıkları problem türünde daha başarılı oldukları gözlenmiştir. Problemlerin bir kriter içermesi durumunda öğrencilerin geriye doğru çalışma stratejisini uygulamada zorlandıkları hatta bazen uygulayamadıkları görülmüştür. $\mathrm{Bu}$ aşamada hemen hemen tüm öğrenciler araştırmacının yönlendirmesine ihtiyaç duymuş ve ancak yönlendirme ile stratejiyi uygulayabildikleri gözlenmiştir. Kriteri anlamaları durumunda ise stratejiyi uygulamakta zorlanmadıkları tespit edilmiştir. Çözüm sürecine ilişkin öğrenci cevaplarından örnek görüntüler Şekil 3'de sunulmuştur.

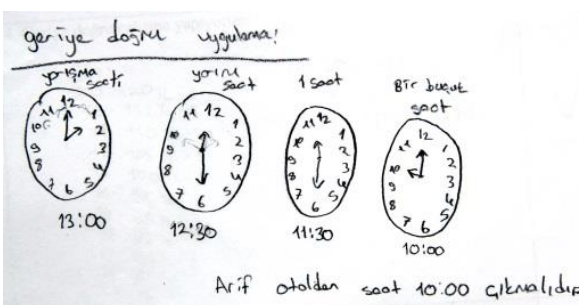

a) $\mathrm{M}$ öğrencisi iki stratejiyi birlikte kullanma

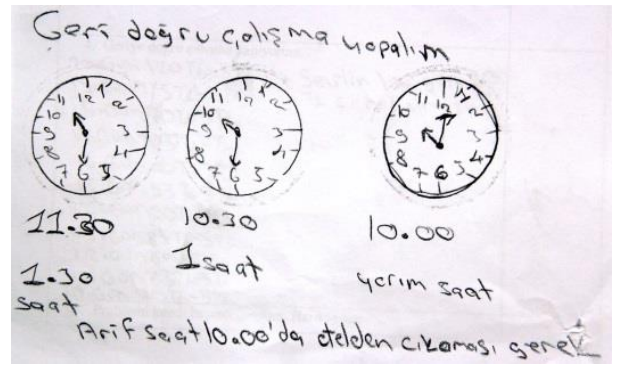

b) $\mathrm{T}$ öğrencisi iki stratejiyi birlikte kullanma

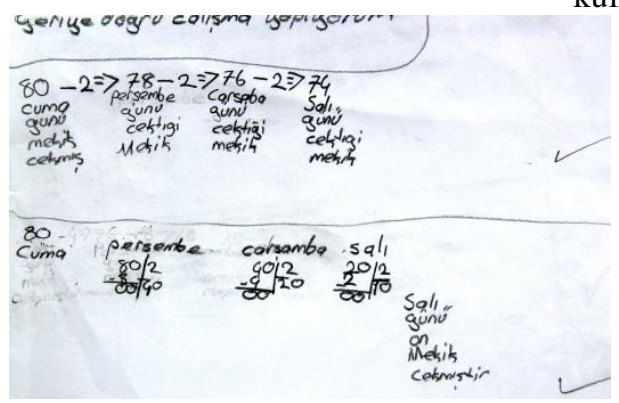

c) K öğrencisi kritere takılma

Şekil 3. Geriye doğru çalışma stratejisine ilişkin örnek öğrenci cevapları

\section{Tartışma ve Sonuç}

Katılımcı hafif düzeyde zihin engelli öğrencilerin eğitim almadan önce problem çözme sürecinde stratejilere sınırlı şekilde başvurdukları ön çalışma bulgularına yansımışken, strateji öğretimi sonrasında stratejileri daha çok ve etkin kullanmaya başladıkları çalışmanın bulgularından anlaşılmaktadır. Öğrencilerin öğretim programlarında yer alan kazanımlara yönelik yapılan öğretimin akademik başarılarına yaptığı katkıya benzer şekilde, görece geliştirilmesi daha zor olan problem çözme stratejilerine yönelik yapılan öğretimin de becerilerini geliştirmede etkili olduğu araştırma bulgularına dayalı olarak söylenebilir. Barrett (1995) araştırmasında, zihinsel engelli çocuklar ile normal gelişim gösteren çocuklar arasındaki problem çözme yeteneklerinde olası farklılıkları incelenmiştir. Zihinsel engelli çocukların ve karşılaştırılabilir zihinsel yaştaki normal gelişim gösteren çocukların, aynı problem çözme stratejilerini kullandıkları ve oyun benzeri görevlerin çözülmesiyle ilgili benzer çözüm zaman oranlarına sahip oldukları tespit edilmiştir. Barrett'in (1995) çalışmasına benzer şekilde; bizim çalışmamızın bulgularına yansıyan hafif düzeyde zihinsel engelli öğrencilerin problem çözme sürecine ilişkin performanslarının, normal gelişim gösteren çocukların problem çözme süreçlerine ilişkin yürütülen literatürdeki çalışma sonuçları ile (Aydoğdu ve Yenilmez, 2012; Baykul ve ark., 2010; Turhan, 2011) örtüştügü söylenebilir. Hafif düzeyde zihinsel engelli öğrencilerin problem çözme sürecinde kullandıkları işlemler, işlem hataları ve stratejiyi kullanma şekilleri seviyelerine uygun karşılaştırılabilir normal gelişim gösteren çocukların durumlarıyla benzerlik göstermektedir.

Problem çözme sürecinde öğrencilerin çözüm için matematiksel işlemlerden, ritmik sayma işlemlerinden, toplama, çıkarma, çarpma ve bölme gibi dört işlem becerilerinden ve zihinden işlem yapma becerilerden faydalandıkları gözlenmiştir. Daha çok işlemsel becerilere dayanan söz konusu davranışları belli oranda kullanıyor olmalarına rağmen hafif düzey zihinsel engelli öğrencilerin, mantık, denklem kurma, akıl yürütme, karmaşık işlemler gibi daha üst düzey becerileri yapmakta normal gelişim gösteren akranlarına göre zorlandıkları ve problem çözmede işe koşamadıkları gözlenmiştir. Bu durumun muhtemel nedeni, hafif düzeyde zihinsel 
engelli öğrencilere matematiksel işlem becerilerinin öğretiminde yanlışsı öğretime dayalı olarak algoritmik bir yaklaşımla (işlem sırasına göre) çok sayıda örnekle öğretim yapılmasıdır. Bu öğretimin temelinde yer alan öğrencilerin işlem sıralarını öğrenmelerinin, ezbere dayalı öğrenmeye benzerlik gösterdiği düşünülmektedir. Çünkü öğrencilerden beklenen, dört işlem gerektiren problemlerde işlemleri algoritmik yaklaşımla uygulayabilmesidir. Öğrencilerin özel gereksinimlerinden dolayı üst düzey beceri gerektiren işlemleri yapabilmeleri işlem becerileri kadar beklenmemektedir. Zihinsel engelli öğrencilerde problem çözme konusu üzerine yapılan Temizöz’ün (2013) araştırmasında, katılımcı öğrencilerin, matematiksel problem çözümünde kavramsal bilgi ağırlıklı değil de işlemsel bilgi ağılıklı bir çözüm yolu takip ettikleri görülmüş̧ür. Çalışmada her ne kadar genel olarak hafif düzeyde zihin engelli öğrencilerin işlemsel becerileri kullanma eğiliminde olsalar da, strateji öğretimi sonunda doğrudan işlemsel becerileri kullanmaktan uzaklaşarak problem çözme stratejilerini kullanmaya çalıştıkları göz ardı edilmemelidir. Araştırmacının gerek uygulama süresince informal gözlemleri ve gerekse öğrencilerin problem çözme kağıtlarından yola çıkarak, katılımcı üç öğrencinin de matematikte problem çözmenin dört işlemden ibaret olmadığı, problem çözerken farklı yollara başvurulabileceği hatta aynı problemin çözümünde birden fazla stratejinin kullanılabileceği konusunda fikirlerinin değiştiği ifade edilebilir.

Araştırmanın öğretim sürecinde, normal gelişim gösteren çocukların problem çözme sürecinde kullanılan Polya'nın problem çözme aşamaları kullanılmıştır. Araştırmanın bulguları Polya'nın problem çözme aşamalarına göre değerlendirilirse; strateji öğretimine başlanılan ilk derslerde, problemi anlama basamağının kritik davranışları olarak sayılan verilenleri belirleme, istenenleri belirleme ve problemi anlatma gibi davranışları (Polya, 2017) öğrencilerin tam olarak gösteremedikleri; bazı problemlerin çözümünde ilerleyemedikleri ve problemi çözmek için sık sık problemi anlamaya dönük geri dönüşler yaptıkları görülmektedir. Öğrencilerin problemi anlamada yaşadıkları en temel güçlük okuduğunu anlamadan kaynaklanmaktadır (Baykul, 2014). Bu durum normal gelişim gösteren çocuklar için de geçerli bir durumdur. Öğretimin başlarında $T$ öğrencisinin problemin verilenlerini oluşturmada başarılı olamadığı fakat öğretimin sonunda verilenleri doğru bir şekilde oluşturmaya başladığı görülmüştür. Diğer iki öğrencinin ise genel olarak öğretimin başından sonuna kadar tüm problemlerde verilenleri ve istenenleri doğru bir şekilde oluşturduğu gözlenmiştir. T öğrencisinin, öğretimin başlarında verilenleri oluşturmada başarılı olamamasının muhtemel nedeni, uygulama öncesi yürütülen matematik problemlerine yönelik öğretimlerde, çözüm sürecinde verilenlerin ve istenenlerin belirtilmesi şeklindeki problemi anlamaya dönük öğretimin yapılmaması, sadece problemi çözmeye odaklı öğretimlerin yapılması olabilir. Çünkü $T$ öğrencisinin araştırma kapsamında uygulanan öğretimin sonuna doğru, verilenleri oluşturmada başarılı olması bu düşünceyi destekler niteliktedir. Problemi anlatma davranışı yönünden ise; tüm problemlerde öğrencilerin hepsi olmasa da, en az birinin, problemi kendi cümleleriyle ifade edebildikleri veya çözüm sürecini anlatabildikleri görülmüştür. Bu davranışlar strateji öğretimi sürecinin sonlarında öğrencilerin problemi anlama basamağını genel olarak başarı ile tamamladıklarının göstergesi kabul edilebilir. Problemin anlama basamağını tamamlamaları durumunda problemin çözümü için plan yaptıkları ve planlarını uygulamaya koyabildikleri söylenebilir. Öğretimden önce öğrencilerin problem çözme yaklaşımlarının genel olarak problemi okuduktan sonra nedenini bilmeden dört işleme başvurmak şeklinde olduğu görülmüştür. Ancak öğretim sürecinde ve öğretim sonu bağımsız değerlendirmelerde, öğrencilerin problemin çözümü için doğrudan dört işlem yapmayı düşünmek yerine öğretimi yapılan stratejilere odaklanarak planlar yaptıkları gözlenmiştir. $\mathrm{Bu}$ durum üç ögrencinin problem çözmede Polya'nın plan yapma aşamasına uygun davranabildikleri düşüncesine ulaştırmış̧ır. Öğrencilerin, tahmin ve kontrol stratejisinin uygulanmasında yaptıkları herhangi bir tahminin doğruluğunu verilenlerle kıyaslama yaparak kontrol ettikleri görülmektedir. Ancak Polya'nın problem çözme sürecinin son aşaması olan kontrol etme ve sağlama yapma aşamasına her üç öğrencinin de hiç başvurmadıkları tespit edilmiştir. Öğrencilerin problem çözme kayıtlarının hiçbirinde, yaptı̆̆ işlemin doğruluğunu kontrol etme veya sağlama yapma davranışına ilişkin herhangi bir gösterge tespit edilememiştir. Bu bulgu normal gelişim gösteren akranları üzerinde problem çözme sürecine ilişkin yapılan çalı̧smaların bulgularıyla benzerlik göstermektedir (Baykul ve ark., 2010).

Araştırmanın problem çözme stratejilerine ilişkin bulguları her bir strateji için ayrı ayrı tartışılmıştır. Tahmin ve kontrol stratejisi, araştırma kapsamında öğretimi yapılan ilk stratejidir. Dolayısıyla öğrencilerin öğretimin ilk safhalarında acemilik yaşadıkları düşünülmektedir. İlk ders planının uygulanmasında zorlandıkları ancak sonra öğretim sürecine adapte olabildikleri görülmüsstür. Tahmin ve kontrol stratejisinin kullanılmasının beklendiği problemlerin yer aldığı bütün bağımsız değerlendirme basamaklarında, katılımcı öğrencilerin tümünün stratejinin doğasını, işleyişini ve kullanma şeklini öğrendikleri düşünülmektedir. Genel olarak öğrencilerin, problemin çözümünde tahmin ve kontrol stratejini seçebildikleri ve stratejiyi uygulamak üzere bir tablo oluşturabildikleri görülmüştür. Tahminleri için oluşturdukları tablonun başlıklarını oluşturmada M öğrencisinin ilk uygulamalarda sorun yaşadığı, başlıkları tamamlamada araştırmacı yönlendirmesine ihtiyaç duyduğu gözlenmiştir. Yönlendirmelerin küçük ipuçları şeklinde ve öğrencileri fark etmeye sevk edecek tarzda olduğu belirtilebilir. Diğer iki öğrencinin bulgularından, tablonun başlıklarını doğru bir şekilde oluşturabildikleri görülmektedir. Öğrencilerin ilk tahminlerini genel olarak rastgele yaptıkları, sonraki tahminlerde ise problemin verilenlerini iyi anlamışlarsa sistematik tahmine geçtikleri söylenebilir. Eğer problemdeki mantı̆̆ çözememişlerse rastgele tahminlerine devam ettikleri, bundan dolayı tahmin sayılarının arttığı düşünülmektedir. Öğrencilerin özellikle 
problemi anlayamadıklarında tahminlerini yapabilmek için araştırmacı yönlendirmesine ihtiyaç duydukları görülmüşsür. Bu sebeple hafif düzeyde zihinsel engelli öğrencilerde problemi anlama basamağının normal gelişim gösteren öğrencilerde olduğu gibi problem çözme sürecinde çok kritik bir adım olduğu ifade edilebilir. Bazı problemleri okurken, problemde verilen bilgileri çok dikkatli okumadıkları, dolayısıyla gözden kaçırdıkları bilgiler olduğu düşünülmektedir. Öğrenci $\mathrm{T}$ ve Öğrenci $\mathrm{K}$ 'nin problemleri anlamakta yaşadıkları zorluk nedeniyle tahmin aşamasına geçemedikleri, yaptıkları tahminlerin doğruluğunu kontrol etme aşamasında işlem hatası yapmaları sebebiyle tahmin sayılarının çok arttı̆̆ 1 görülmektedir. Bu durumun öğrencilerde daha fazla kafa karışıklığına ve sonuca ulaşmada ciddi sorun yaşamalarına neden olduğu söylenebilir. Böyle durumlarda araştırmacı yönlendirmesi olmadan problemi çözemedikleri tespit edilmiştir.

Öğrenci T'nin bir problemin çözümünde, öğretimi yapılan stratejinin yanında öğretimi yapılmayan "uç değerleri kullanma ve akıl yürütme" stratejisine başvurması çok dikkat çekicidir. Bu durum öğrencinin kendisinden beklenmedik biçimde, problemde kendi problem çözme stratejisini seçip uygulamaktan çekinmediğini göstermektedir. Öğrenci problemi kendi tercih ettiği stratejiyle çözmüş ve doğru sonuca ulaşmıştır. Bu durum öğrencinin bir problemin sadece bir stratejiyle çözülmesi gerektiği algısını taşımadığını, hatta çözümde birden fazla stratejinin kullanılabileceği düşüncesinde olduğu gösterir. İlköğretim birinci sinıf öğrencilerinin problem çözme stratejilerini kullanabilme düzeylerini incelediği araştırmasında Çelebioğlu (2009), birinci sınıf öğrencilerinin öğretimi yapılmadığı halde strateji kullanabildiklerini rapor etmiştir. Bu bulgu, T öğrencisinin öğretimini almadığı halde "uç değerleri kullanma stratejini" kullanabilmesi ile benzerdir.

Tahmin ve kontrol stratejisinin son bağımsız uygulama sorusunda öğrencilerin tümü benzer süreci yaşamışlardır. Problem içerisinde yer alan ikinci bir kriterin, öğrencilerin stratejiyi uygulamalarında önemli bir engel oluşturduğu görülmüsstür. Bu kriterin hem içeriği hem de fazladan yönerge oluşturması, öğrencilerin stratejiyi uygulamada başarısız olmalarına neden olmuştur. Öğrencilerin, problem içerisinde "katı, fazlası, eksiği, yarısı gibi kriterlerle karşılaşmaları ve problemde birden fazla yönergenin bulunması" öğrencilerin daha önce çok karşılaşmadıkları bir durum olarak değerlendirilmiş ve bu tür problemlerin çözümünde ne yapacaklarını bilemedikleri görülmüştür. Sonuç olarak söz konusu kriterin üstesinden öğrencilerin kendi başlarına gelemedikleri, bu durumda stratejiyi kullanamadıkları, ancak araştırmacı yönlendirmesi ile problemi çözebildikleri görülmüştür.

Şekil, Şema ve Diyagram Çizme Stratejisi, üç öğrencinin de en başarılı olduğu strateji olarak değerlendirilebilir. Çünkü öğrenciler şekil, şema ve diyagram çizme stratejisini seçmede ve probleme uygun şekiller çizmede başarılı olmuşlardır. Öğrenci M'nin şekillerinin özellikle problemin bağlamına uygun şekiller olması dikkat çekmektedir. Aynı şekilde K öğrencisinin şekilleri arasında problemin bağlamına uygun şekiller görmek mümkündür. $T$ öğrencisinin ise problemin şekillerini çizerken problemin bağlamına uygun şekiller çizmek için uğraşmak yerine problemin verilenlerine uygun sembolik şekilleri tercih ettiği söylenebilir. Bunun yanı sıra üç öğrencinin de çizdikleri şekillerin problemin verilenlerini ve istenenlerini yansıttığ görülmektedir. Problem çözümlerinde şekilleri çizebilmiş olmasına rağmen problemlerde yer alan ilave kriterlerin öğrencileri yine zorladığı ve problemi çözme noktasında yönlendirme olmadan ilerleyemedikleri görülmüştür. K öğrencisinin 2., 3. ve 4. problemlerde kritere takıldığı, bu kriterleri aşmakta zorlandığ 1 ve araştırmac1 yönlendirmesi olmadan çözemediği görülmüştür. Öğrencinin üç soruda da aynı sorunu yaşamış olması, öğrencinin bireysel farklılıklarından kaynaklanan bir durum olabileceğini akla getirmektedir. Üç öğrencinin de yine problemlerdeki ilave kriterlerde zorlandıklarını söylemek mümkündür.

Geriye doğru çalışma stratejisi bulgularına göre; öğrencilerin üçünün de stratejiyi seçip, stratejiyi uygulama aşamasına başlayabildikleri tespit edilmiştir. K öğrencisinin bütün problemlerde geriye doğru çalışma stratejisini uygulamakta zorlandığ 1 görülmüştür. Gitmesi gereken yerleri karıştırdığı, geriye gitmesi gereken saatleri karıştırdığı ve son problemde yine kritere takılarak araştırmacının yönlendirmesi ile ilerleyebildiği görülmektedir. K öğrencisi geriye doğru çalı̧̧ma stratejisinde, verilenlerden yola çıarak geriye doğru bir yol izlemesi gerektiğini ifade edebilmekte ancak uygulayamamaktadır. Buradan hareketle, K öğrencisinin geriye doğru çalş̧ma stratejisinin doğasını anladığı ama bunu uygulamada başarılı olmadığı düşünülmektedir. K öğrencisinin diğer iki stratejiyi kullanabilmede daha başarılı olduğu araştırma bulgularından anlaşılmaktadır. T öğrencisinin geriye doğru çalışma stratejilerine ilişkin problemlerden sadece son problemdeki kriterde takılı kaldığ 1 görülmüsstür. Bunun nedeni olarak problemde yer alan kriteri anlamakta ve uygulamakta zorlandığ 1 düşünülmektedir. Diğer problemlerde $T$ öğrencisinin geriye doğru çalışma stratejisini uygulayabildiği söylenebilir. M öğrencisinin de son problemdeki kritere takılı kaldığı, problemdeki kriteri anlamakta ve uygulamada zorlandığı görülmüştür. Her üç öğrenci de son sorunun kriterini ancak araştırmacı yönlendirmesi ile anlayabilmiş̧ir. Önemli bulgulardan biri $\mathrm{M}$ ve $\mathrm{T}$ öğrencilerinin saat problemlerinde problemi geriye doğru çözerken işlem yaparak saatleri hesaplayıp yazmalarının yanı sıra bir önceki öğrendikleri şekil, şema ve diyagram çizme stratejisini kullanarak saat modelleri çizip problemi bu modeller üzerinde çözmeleridir. $\mathrm{Bu}$ durum, öğrencilerin daha önceki öğrendikleri stratejiyi genelleyerek başka problemlerde de kullanabildiklerini ve iki stratejiyi birlikte kullanabildiklerini göstermektedir. Yani öğrenciler öğrendikleri stratejiyi mevcut problemlerle sınırlandırmayıp, farklı problemlerde de kullanabilmektedirler. 
Üç stratejiye ilişkin bulgular birlikte değerlendirildiğinde; üç öğrencinin problemi anlama basamağında verilenleri, istenenleri yazabildikleri ve gerektiğinde kendi cümleleriyle problemi anlatabildikleri görülmüştür. Problemin çözümü için uygun stratejiyi belirleyip o yönde adımlar atabildikleri gözlenmiştir. Problemin çözümü için yapılması gereken işlemleri yapmaya çalıştıkları, çözüm sürecinde yaptıklarını anlatabildikleri tespit edilmiştir. Problemi tam olarak anladıklarında doğru sonucu bulabildikleri, eğer problemi anlamadılarsa yönlendirme yapılması gerektiği düşünülmektedir. Problemlerin içerisinde ilave kriter ve fazladan yönerge olması durumunda, öğrencilerin problemi çözmede zorlandığı ve hatta kendi başlarına bu problemleri çözemedikleri görülmektedir. Böyle durumlarda yönlendirmelerin olması gerektiği düşünülmektedir. $\mathrm{O}$ yüzden bu öğrencilere yöneltilecek problemlerin içerisinde çok fazla kriterin olmaması ve az sayıda yönerge içermesi gerektiği düşünülmektedir. Problem çözme stratejilerine yönelik öğretimin bu üç öğrencinin problem çözme başarılarında etkili olduğu düşünülmektedir. Nar'ın (2018) temel toplama işleminin öğretiminde somut-yarı somut-soyut öğretim stratejisinin etkili olduğunu göstermesi; Rumiati'nin (2017) onluk kartların ve abaküslerin kullanılmasının, hafif zihinsel engelli ergenlerin toplama ve çıkarma problemlerini çözme stratejilerini geliştirmek için faydalı olabileceğini göstermesi; Casner'ın (2016) araştırmaya katılan öğrencilerin çoğunun şema temelli öğretim sonucunda öğrendiklerini ve matematiksel problem çözme becerileri geliştirdiklerini göstermesi; Kot'un (2014) araştırmasında, doğrudan öğretim yöntemiyle sunulan şemaya dayalı öğretim stratejisinin zihinsel yetersizlikten etkilenmiş çocukların matematiksel problem çözme performanslarında etkili olduğunu belirtmesi; Altun ve Arslan'ın (2006) ilköğretim öğrencilerinin problem çözme stratejilerini öğretme amacı ile hazırlanan ortamın bazı stratejilerin öğretiminde etkili olduğunu belirtmesi bizim araştırma sonuçlarımızla benzerlik göstermektedir.

\section{5. Öneriler}

- Araştırma kapsamında elde edilen bulgu ve sonuçlar, hafif düzeyde zihinsel engelli öğrencilere problem çözme stratejilerine yönelik öğretimlerin yapılmasının, öğrencilerin normal gelişim gösteren akranları ile aralarındaki farkları azalttığını; problemlerde doğrudan işlemsel becerilere odaklanmak yerine farklı stratejileri kullanmaya ve problem çözme sürecinin adımların uygun davranışlara yönelttiğini işaret etmektedir. Buradan hareketle, hafif düzeyde zihin engelli öğrencilerle çalışan matematik ve özel eğitim öğretmenlerinin matematiksel problem çözme stratejilerinin öğretimini sabırla yapmaya çalışmaları, bu süreçte Polya'nın problem çözme sürecine benzer şekilde sistematik yaklaşımların kullanılması önerilmektedir.

- Hafif düzeyde zihinsel engelli öğrencilerde problemi anlama basamağının normal gelişim gösteren öğrencilerde olduğu gibi problem çözme sürecinde çok kritik bir adım olduğu görülmüştür. Bu adımda öğrenciler ile problemi anlama basamağının göstergesi kritik davranışlara odaklanan, yalnızca problemi anlamaya dönük çalışmaların yapılması önerilmektedir.

- Hafif düzeyde zihinsel engelli öğrencilerin problem çözümünde kendi stratejilerini geliştirebildikleri, tercih ettikleri herhangi bir ya da birkaç stratejiyi birlikte kullanabildikleri, öğrendikleri bir stratejiyi başka bir problemin çözümünde kullanabildikleri göz önünde bulundurulursa; öğretmenlerin öğrencilerin kendi stratejilerini seçmelerine imkan sağlamaları, farklı stratejilerin öğretimine yönelik tedbirlerin alınması önerilmektedir.

- Hafif düzeyde zihinsel engelli öğrencilerde, problem çözme becerisi üzerine hazırlanan öğretim sürecinde, çözümü yapılacak olan problemlerin, öğrencinin aklını karıştıracak kriterler ve öğrencide karmaşıklığa neden olacak yönergeler içermemesine, öğrencinin seviyesine uygun kriter ve yönergeler içermesine dikkat edilmesi önerilmektedir.

- Hafif düzeyde zihinsel engelli öğrencilere problem çözme stratejilerinin öğretiminde doğrudan öğretim yöntemine uygun ders planlarının hazırlanarak öğretimin yapılması ve özellikle bu süreçte takip formundan yararlanılması önerilmektedir.

- Öğretmenlerin, matematik dersinde öğrencilerin problem çözüm sonuçlarını kontrol edip, sağlama yapma becerilerini geliştirmeleri için ders planlarını bu becerileri geliştirecek şekilde düzenleyip uygulamaları önerilmektedir.

Problem çözme öğretiminde, öğrencilerin ilgilerini çekecek, günlük yaşantıdan örnekler içeren ve öğrencilerin çözmekten mutlu olacakları problemlerin tercih edilmesi önerilmektedir.

\section{Kaynaklar / References}

Altun, M. (2008). Liselerde matematik ögrretimi. Bursa: Aktüel Alfa Akademi Bas. Yay. Dağ. Ltd. Şti.

Altun, M. ve Arslan, Ç. (2006). İlköğretim öğrencilerinin problem çözme stratejilerini öğrenmeleri üzerine bir çalışma. Uludă̆ Üniversitesi Ĕgitim Fakültesi Dergisi, 19(1), 1-21.

American Association on Mental Retardation [AAMR]. Luckasson, R., Borthwick-Duffy, S., Buntinx, W. H. E., Coulter, D. L., Craig, E. M. (P.), Reeve, A., Schalock, R. L., Snell, M. E., Spitalnik, D. M., Spreat, S., Tassé, 
M. J., \& The AAMR AD HOC Committee on Terminology and Classification. (2002). Mental retardation: Definition, classification, and systems of supports (10th ed.). Washington, D.C.: American Association on Mental Retardation Press.

American Psychiatric Association [APA]. (2013). Diagnostic and statistical DSM-5 (5th ed.). Washington, DC: American Psychiatric Publishing.

Aydoğdu, N. ve Yenilmez, K. (2012, Haziran). Matematikte problem çözme becerisiyle ilgili yapılan çalışmaların incelenmesi. X. Fen Bilimleri ve Matematik Eğitimi Kongresi’nde sunulan bildiri, Niğde.

Bağlama, B. (2018). Zihin yetersizliği olan öğrencilere matematik problem çözme becerisinin ögretiminde doğrudan ögretim yöntemiyle sunulan bilgisayar destekli video ile model olma öğretiminin etkililiğ (Yayımlanmamış doktora tezi). Yakın Doğu Üniversitesi, Eğitim Bilimleri Enstitüsü, KKTC.

Barrett, S. (1995). Problem solving of children with intellectual disabilities: Interrogative strategies and solution time rates (Honours Theses). Edith Cowan University, Faculty of Educalion, Joondalup, Australia.

Baykul, Y. (2014). Illkokulda matematik ögretimi. Ankara: Pegem Akademi.

Baykul, Y., Sulak, H., Doğan, A., Doğan, M., Yazıcı, E., Sulak, S., Peker, B. \& Kurnaz, A. (2010). Problem çözme stratejileri. Konya: Gençlik Kitabevi Yayınları.

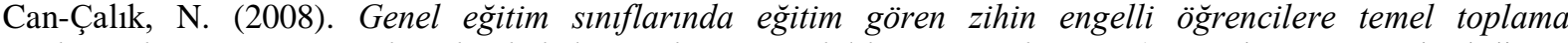
becerilerinin öğretiminde nokta belirleme tekniğinin etkililiğinin incelenmesi (Yayımlanmamış yüksek lisans tezi). Ankara Üniversitesi, Eğitim Bilimleri Enstitüsü, Ankara.

Casner, B. (2016). A mixed method study on schema-based instruction, mathematical problem solving skills, and students with an educational disability. (Unpublished doctoral dissertation). Lindenwood University, the USA.

Cihak, D. (2010). Effects of the touchmath program compared to a number line strategy to teach addition facts to middle school students with moderate intellectual disabilities. Education and Training in Autism and Developmental Disabilities, 45(3), 449-458.

Çelebioğlu, B. (2009). İlköğretim birinci sınıf öğrencilerinin problem çözme stratejilerini kullanabilme düzeyleri (Yayımlanmamış yüksek lisans tezi). Uludağ Üniversitesi, Fen Bilimleri Enstitüsü, Bursa.

Davis, L. (2016). Effects of peer-mediated instruction on mathematical problem solving for students with moderate/severe intellectual disability (Unpublished doctoral dissertation). The University of North Carolina, the USA.

Engelmann, S. (1998). Psychology learning resources Siegfried Engelmann and direct instruction. Retrieved October 9, 2019 from https://psych.athabascau.ca/open/engelmann/bio.php.

Engelmann, S., \& Carnine, D. (1991). Theory of instruction: Principles and applications (Revised ed.). Eugene, Oregon: Nifdi Press.

Eripek, S. (1998). Özel eğitim. Eskişehir: Anadolu Üniversitesi Yayınları.

Eripek, S. ve Vuran, S. (2016). Zihinsel yetersizliği olan çocukların eğitimi. G. Akçamete (Ed.), Genel eğitim okullarında özel gereksinimi olan ögrenciler ve özel eğitim içinde (ss. 245-282). Ankara: Kök Yayıncıllı.

Harris, K., \& Graham, S. (1992). Improving the mathematical problem-solving skills of students with learning disabilities: Self-regulated strategy development. The Journal of Special Education, 26(1), 1-19.

Karabulut, A. (2015). Anla ve çöz! Stratejisi'nin hafif düzeyde zihinsel yetersizliği olan ögrencilerin matematik problemi çözme becerisindeki etkisinin belirlenmesi (Yayımlanmamış doktora tezi). Gazi Üniversitesi, Eğitim Bilimleri Enstitüsü, Ankara.

Karataş, Z. (2017). Sosyal bilim araştırmalarında paradigma değişimi: Nitel yaklaşımın yükselişi. Türkiye Sosyal Hizmet Araştırmalarl Dergisi, 1(1), 70-86.

Kot, M. (2014). Zihinsel yetersizliği olan öğrencilere problem çözme becerisinin öğretiminde semaya dayalı ögretim stratejisinin etkililiği (Yayımlanmamış yüksek lisans tezi). Abant İzzet Baysal Üniversitesi, Fen Bilimleri Enstitüsü, Bolu.

Metin, E. N. ve Işıtan, S. (2017). Zihinsel engelli çocuklar ve eğitimleri. N. Baykoç (Ed.), Özel gereksinimli çocuklar ve özel eğitim içinde (ss. 159-182) Ankara: Eğiten Kitap Yayıncılık.

Miles, M. B., \& Huberman, A. M. (1994). An expanded sourcebook qualitative data analysis. California: SAGE Publications.

Milli Eğitim Bakanlığ1 [MEB]. (2018). Özel eğitim matematik dersi programı. Ankara: Özel Eğitim Müdürlüğü.

Nar, S. (2018). Zihin yetersizliği olan öğrencilere temel toplama işleminin öğretiminde somut-yart somut-soyut ögretim stratejisinin etkililiği (Yayımlanmamış yüksek lisans tezi). Anadolu Üniversitesi, Eğitim Bilimleri Enstitüsü, Eskişehir.

Polloway, E., Serna, L., Patton, J., \& Bailey, J. (2014). Özel gereksinimi olan öğrenciler için öğretim stratejileri (Z. Bahap Kudret, Çev.). Ankara: Nobel Akademik Yayıncılık.

Polya, G. (1962). Mathematical discovery on understanding, learning, and teaching problem solving, Volume I. New York Chichester Brisbane Toronto, the USA: Ishi Press.

Polya, G. (2017). Nasıl çözmeli matematiksel yönteme yeni bir bakış (B. S. Soyer, Çev.). Ankara: Tübitak Popüler Bilim Kitapları. 
Posamentier, A. S. \& Krulik, S. (1998). Problem-solving strategies for efficient and elegant solutions: A resource for the mathematics teacher. California: Corwin Press, Inc.

Rumiati, M. (2017). Strategies for addition and subtraction in the range 1 to 100 of adolescents attending a special school for the intellectually disabled in Indonesia (Unpublished master's thesis). Southern Cross University, Indonesia.

Santos-Trigo, M. (1998). Instructional qualities of a successful mathematical problem-solving class. International Journal of Mathematical Education in Science and Technology, 29(5), 631-646.

Steffe, L. \& Thompson, P. (2000). Teaching experiment methodology: Underlying principles and essential elements. In R. A. Lesh \& A. E. Kelly (Eds.), Research design in mathematics and science education (pp. 267-307). New Jersey: Erlbaum.

Sucuoğlu, B. (2016). Zihinsel engellilerin eğitimi. B. Sucuoğlu (Ed.), Zihin engelliler ve eğitimleri içinde (ss. 203-238). Ankara: Kök Yayıncılık.

Temizöz, Y. (2013). Illkögrretim ve ortaöğretim öğrencilerinin matematiksel problem çözme sürecinde kavramlar ile ilgili anlayışlarının ve kavram-işlem kullanımlarının rolü (Yayımlanmamış doktora tezi). Gazi Üniversitesi, Eğitim Bilimleri Enstitüsü, Ankara.

Tufan, S. (2016). Şemaya dayalı strateji ve kendini izlemenin hafif düzeyde zihinsel engelli öğrencilerin sözlü problem çözme performanslarına etkisi (Yayımlanmamış yüksek lisans tezi). Gazi Üniversitesi, Eğitim Bilimleri Enstitüsü, Ankara.

Tuncer, A. (2009). Şemaya dayalı sözlü matematik problemi çözme stratejisinin görme yetersizliği olan öğrencilerin sözlü problem çözme performanslarına etkisi. Eğitim ve Bilim, 34(153), 183-197.

Turhan, B. (2011). Problem kurma yaklaşımı ile gerçekleştirilen matematik öğretiminin ilkögretim 6 . sınıf ögrencilerinin problem çözme başarlları, problem kurma becerileri ve matematiğe yönelik görüşlerine etkisinin incelenmesi (Yayımlanmamış yüksek lisans tezi). Anadolu Üniversitesi, Eğitim Bilimleri Enstitüsü, Eskişehir.

Yıldırım, A. ve Şimşek, H. (2008). Sosyal bilimlerde nitel araştırma yöntemleri. Ankara: Seçkin Yayıncılık. 